Federal Reserve Bank of Dallas

Globalization and Monetary Policy Institute

Working Paper No. 79

http://www.dallasfed.org/assets/documents/institute/wpapers/2011/0079.pdf

\title{
Low Interest Rates and Housing Booms: the Role of Capital Inflows, Monetary Policy and Financial Innovation*
}

\author{
Filipa Sá \\ Trinity College \\ University of Cambridge \\ Pascal Towbin \\ Banque de France \\ Tomasz Wieladek \\ London Business School
}

April 2011

\begin{abstract}
A number of OECD countries experienced an environment of low interest rates and a rapid increase in real house prices and residential investment during the past decade. Different explanations have been suggested for the housing boom: expansionary monetary policy, capital inflows due to a global savings glut and excessive financial innovation combined with inappropriately lax financial regulation. In this study we examine the effects of these three factors on the housing market. We estimate a panel VAR for a sample of OECD countries and identify monetary policy and capital inflows shocks using sign restrictions. To explore how the effects of these shocks change with the structure of the mortgage market and the degree of securitization, we allow the VAR coefficients to vary with mortgage market characteristics. Our results suggest that both types of shocks have a significant and positive effect on real house prices, real credit to the private sector and residential investment. The response of housing variables to both types of shocks is stronger in countries with more developed mortgage markets. The amplification effect of mortgage-backed securitization is particularly strong for capital inflows shocks.
\end{abstract}

JEL codes: C33, E51, F32, G21

\footnotetext{
* Filipa Sá, Trinity College, University of Cambridge, Trinity Street, CB2 1 TQ, United Kingdom. Fgs22@cam.ac.uk. + 44 - (0) 20-7601-5940. Pascal Tobin, Banque de France. 31 rue Croix des petits champs, 75001 Paris - France. 01-42-92-42-92. Pascal.Towbin@banque-france.fr. Tomasz Wieladek, London Business School. tomasz.wieladek@bankofengland.co.uk. The authors wish to thank Shekhar Aiyar, Martin Brooke, Stefan Gerlach, Glenn Hoggarth, Daniel Kaufmann, Alfred Lehar, Lavan Mahadeva, Gregory Thwaites, Cédric Tille, Sebastian Weber, Charles Wyplosz, and participants at several conferences for helpful comments and suggestions. Part of this research was conducted while Pascal Towbin was at the Graduate Institute, Geneva and funding from the Swiss National Science Foundation is gratefully acknowledged. The views in this paper are those of the authors and do not necessarily reflect the views of the Bank de France, the Federal Reserve Bank of Dallas or the Federal Reserve System.
} 


\section{Introduction}

The run-up to the recent global financial crisis was characterised by an environment of low interest rates and a rapid increase in housing market activity across OECD countries. The link between the two is intuitive: low interest rates make credit cheaper and increase the demand for housing. Some scholars argue that expansionary monetary policy was responsible for the low level of interest rates and the subsequent house price boom - for example, Hume and Sentance (2009) and Taylor (2009). Others contend that the low degree of financial development in emerging market economies led to capital inflows to developed countries, depressing long term interest rates and stimulating an increase in the demand for housing - for example, Caballero et al. (2008), Warnock and Warnock (2009) and Bernanke (2010). Figure 1 provides support for this hypothesis, showing that in the period from 1999 to 2006 house prices rose by more in countries with larger current account deficits. This negative correlation suggests the presence of an important link between the current account balance and the housing sector, but the direction of causality is unclear.

One other factor which is thought to have played a role in amplifying the effect of interest rate movements on housing activity is financial innovation. In more developed mortgage markets, consumers have easier access to credit and tend to be more leveraged. In the presence of financial frictions, the impact of changes in interest rates on consumer wealth and the housing market should become stronger when leverage is higher. This is the idea behind the financial accelerator effect developed by Bernanke and Gertler (1989) and Kiyotaki and Moore (1997). In addition to this effect, there may also be amplification through securitization. Diamond and Rajan (2009) argue that excessive securitization has led to a misallocation of capital to the real estate sector, exacerbating the effect of interest rate movements on housing activity.

Each of these explanations has different policy implications. Should policy makers try to address external imbalances, increase financial regulation or redesign the monetary policy framework to prevent future boom and bust episodes in the housing market?

In this study we estimate a Vector Autoregressive (VAR) model for a panel of 18 OECD countries and look at the effects of capital inflows, monetary policy and financial innovation on the housing sector. Monetary policy and capital inflows shocks are identified using the sign restrictions approach developed by Canova and de Nicoló (2002) and Uhlig (2005). We look at the effect of both types of shocks on real credit to the private sector, real residential investment, and real house prices. We also assess whether the degree of mortgage market development or legislation permitting issuance of mortgage-backed securities amplify or dampen the impact of these shocks on the housing sector.

Previous work using VAR models to analyse the housing market has focused on the transmission of monetary policy shocks in advanced economies - for example, Assenmacher-Wesche and Gerlach (2010), Carstensen et al. (2009), Calza et al. (2009) and Goodhart and Hoffmann (2008).

At the same time, there is a substantial literature looking at the "capital inflows problem" and its implication for asset prices in developing economies — for example, Calvo et al. (1994) but studies examining this link for advanced economies are still scarce. For example, Reinhart and Reinhart (2008) find that large capital inflows in both advanced and emerging economies are 
associated with a real exchange rate appreciation and booms in equity and house prices. Similarly, Aizenman and Jinjarak (2009) document a negative relationship between current account balances and real house price growth in a broad sample of developed and developing countries, like the one displayed in Figure 1 for OECD countries.

Our paper brings together these two strands of literature, looking at the effect of both capital inflows and monetary policy shocks. In this respect, it is closest to Sá and Wieladek (2010), who estimate an open-economy VAR model for the United States and use sign restrictions derived from a 2-country DSGE model to identify the effect of both shocks on the housing market. They find that capital inflows shocks explain a substantial amount of the variation in real house prices and residential investment in the United States. While Sá and Wieladek (2010) only focus on the United States, we look at a broader sample of all OECD countries.

Another contribution of this paper is to study the role of financial innovation in the transmission of monetary policy and capital inflows shocks to the housing sector. We first separate our sample into a group of countries with high mortgage market development and a group of countries with low mortgage market development. Countries are classified using an index constructed in IMF (2008), which takes a higher value if typical loan-to-value ratios are high, there is the possibility of mortgage equity withdrawal (i.e. consumers can borrow against the value of their houses to finance spending), secondary mortgage markets exist, and mortgage contracts are predominantly long term. We estimate our panel VAR model separately for these two groups of countries and compare their impulse responses following monetary policy and capital inflows shocks.

To study how securitization affects the transmission of capital inflows and monetary policy shocks to the housing market we use a de jure index constructed by Hoffman and Nitschka (2009) which captures the extent to which securitization is allowed in different countries. The index varies both across countries and across time. Splitting the sample into groups would neglect the time variation. To exploit the time variation in this index, we estimate an interacted panel VAR model, as in Towbin and Weber (2010). By interacting all variables with an index of mortgagebacked securitization, we allow the responses to vary with the degree of securitization. We then compare impulse responses evaluated at high and low levels of securitization.

Some previous studies have looked at whether the structure of the mortgage market plays a role in the propagation of monetary policy shocks. Calza et al. (2009) and Assenmacher-Wesche and Gerlach (2010) find that higher mortgage market development amplifies the effects of monetary policy shocks on housing variables. Both studies estimate panel VAR models across two groups of countries, classified according to their degree of mortgage market development using various crosssectional indicators. Our approach is similar to theirs, but differs in three important ways. First, we identify the effect of capital inflows shocks in addition to monetary policy shocks. Second, we use sign restrictions rather than zero restrictions for identification of the shocks. ${ }^{1}$ Third, we estimate an interacted panel VAR which allows us to study the effects of time-varying characteristics of the

\footnotetext{
${ }^{1}$ See Canova and de Nicoló (2002) or Uhlig (2005) for a critique of the use of zero restrictions to identify monetary policy shocks.
} 
mortgage market without having to split the sample in sub-groups.

Our results suggest that both monetary policy and capital inflows shocks have a significant and positive effect on house prices, credit to the private sector and residential investment. A reduction of 10 basis points on long term nominal interest rates caused by an expansionary monetary policy shock raises real credit and house prices by about $0.3 \%$ after ten quarters and real residential investment by about $0.2 \%$. A similar reduction in long rates caused by a capital inflows shock has a larger effect, with the rise in real credit to the private sector and real house prices reaching a peak of about $0.5 \%$ after seven quarters. The response of real residential investment to capital inflows shocks is quicker and more short-lived, peaking at $0.7 \%$ after two quarters.

The effects of both shocks are greater in countries with a higher degree of mortgage market development. This suggests that excessive financial innovation may act as a propagation mechanism. The existence of mortgage-backed securities has a much larger effect on the transmission of capital inflows shocks. Legislation permitting the issuance of mortgage-backed securities increases the impact of capital inflows shocks on real house prices, real residential investment and real credit to the private sector by a factor of two. This may be explained by the fact that securitization transforms illiquid, low-grade loans into publicly traded assets of higher quality which are attractive to foreign investors. In this way, securitization increases the share of foreign capital inflows allocated to home mortgage loans, amplifying the effect of capital inflows on the domestic housing market. Our results suggest that persistent capital inflows, coupled with securitization, played a significant role in the housing booms observed in some countries in the run-up to the financial crisis.

The paper proceeds as follows. Section 2 looks at the literature on the transmission channels of interest rates to housing activity and discusses how financial innovation may amplify those channels. Section 3 discusses the methodology and data. The main results are presented in section 4 and various robustness checks in section 5 . Section 6 concludes.

\section{The Transmission Channels of Interest Rates to Housing Mar- kets}

Bernanke and Gertler (1995) and Mishkin (2007) survey the literature on potential transmission channels between interest rates and the real economy. While their focus is on interest rate changes caused by monetary policy, the same channels would be in place for interest rate changes caused by capital inflows. In a neoclassical world the user cost of capital is the only transmission channel: lower interest rates on bonds decrease the opportunity cost of buying a house and increase the demand for houses. In the presence of information asymmetries between borrowers and lenders or other types of financial frictions, there is an additional transmission channel - the financial accelerator effect, developed in the seminal papers of Bernanke and Gertler (1989) and Kiyotaki and Moore (1997).

Bernanke and Gertler (1989) focus on the investment decision of firms. There is asymmetric information between lenders and entrepreneurs: while entrepreneurs know the profitability of their 
investment projects, lenders must pay an auditing cost to observe the project's return. This information asymmetry is the key source of persistence in the model. A negative real interest rate shock increases the profits of entrepreneurs and lowers agency costs, making it easier for them to obtain external finance. As a result, more investment projects are financed, which creates employment for young agents and leads to further income expansion in subsequent periods.

Kiyotaki and Moore (1997) add an additional element to this story: the idea that the net worth of borrowers changes not only in response to variations in cash flows, but also to changes in the value of their assets. In their framework agents can only borrow against collateral (for example, land) and the amount they can borrow depends on the value of collateral. The need for collateral in this model arises not because of asymmetric information but because of limited commitment, i.e. lenders cannot force borrowers to work in order to repay their debt. The dynamic interaction between the borrowing constraint and the value of collateral generates both persistence and amplification. A temporary increase in interest rates reduces borrowers' net worth and tightens their credit constraint. Borrowers cut back on their investment expenditure (including investment in land) and their net worth next period falls as they earn less revenue. This is analogous to the persistence effect in Bernanke and Gertler. But there is an additional effect that operates through the price of land. To ensure market clearing, demand for land by lenders has to rise, which requires a reduction in the user cost of land (the difference between that period's land price and the discounted value of the land price in the following period). The anticipated decline in user costs in subsequent periods leads to an even larger fall in the price of land in the current period, since the price of land equals the discounted value of future user costs. The fall in the price of land reduces net worth of borrowers in the current period even further and has a large impact on their investment spending since they are highly leveraged. There is an amplification effect that occurs because the price of land is forward looking and borrowers are highly leveraged.

The empirical relevance of the financial accelerator effect has been studied, for example, in Bernanke, Gertler and Gilchrist (1999). This study presents a dynamic general equilibrium model that incorporates both the persistence effect in the original Bernanke and Gertler (1989) model and endogenous changes in asset price which generate further amplification, as in Kiyotaki and Moore (1997). A number of studies - for example, Iacoviello (2005) and Calza et. al (2009) — apply the financial accelerator to the housing market, where a similar mechanism is at work. A reduction in interest rates increases the value of collateral (housing) by increasing the discounted value of future user costs. The borrowers' debt capacity and consequently the demand for housing increases further, generating an even larger increase in house prices. Persistence and amplification would be mutually reinforcing and propagate the effect of the initial shock to interest rates on housing activity.

These studies predict that the transmission channels would be stronger in countries with more developed mortgage markets. Higher loan-to-value ratios reinforce the amplification effect described in Kiyotaki and Moore (1997) as households are more leveraged and their net worth is more affected by fluctuations in the value of collateral. The possibility of mortgage equity withdrawal (i.e., the 
possibility to borrow against the value of the house to finance spending) should have a similar effect. Countries where it is less costly to refinance mortgages should also see stronger transmission from interest rates to housing activity, since interest rate reductions would feed through to lower mortgage rates not only for new mortgages but also for existing ones. This would lower the cost of credit and increase housing demand.

There is yet an additional channel through which interest rates may affect house prices: the risk taking channel, proposed by Rajan (2005) and Borio and Zhu (2008). According to this theory, low interest rates encourage financial intermediaries to take more risk, for example because they target a certain rate of return and need to take more risk to achieve that target when risk-free interest rates are lower (a search for yield effect). This would lead to an increase in demand for riskier assets, driving up their prices. The underpricing of risk may also lead to more lenient lending standards, for example higher loan-to-value ratios or lending to households with higher default risk. This would increase borrowers' leverage and strengthen the amplification effect of changes in collateral values described above. Hence, there may be an interesting interaction between the risk taking channel and the financial accelerator.

Diamond and Rajan (2009) argue that securitization also plays an important role in the transmission of interest rate shocks to the housing market. Securitization allows banks to share risks by moving them off their balance sheets. This leads to an increase in banks' risk appetite and strengthens the risk taking channel described above. To the extent that banks become more lenient in their lending standards, the financial accelerator effect may be strengthened as well. By amplifying these transmission channels, securitization may play a role in propagating the effects of interest rate reductions on housing activity. Diamond and Rajan also highlight that securitization facilitates foreign investment in mortgage loans. Without securitization, it is difficult for foreign investors to hold home mortgage loans directly, because they are of uncertain credit quality and have a higher propensity to default than other assets. Securitization packages mortgages together and slices them in different levels of risk. The riskiest tranches can be bought by investors with higher risk appetite, while the AAA tranches can be sold to international investors. In this way, securitization increases the share of foreign capital inflows allocated to home mortgage loans. This would suggest that securitization may have a particularly strong role in the transmission of capital inflows shocks to the housing market, a conjecture which is supported by our empirical results.

\section{Methodology}

\subsection{Data}

We estimate an open economy VAR model for a panel of eighteen OECD countries. ${ }^{2}$ The model includes twelve variables: the consumer price index, real consumption, real non-residential investment, short-term interest rates, long-term interest rates, the ratio of the current account balance

\footnotetext{
${ }^{2}$ The sample includes Australia, Belgium, Canada, Finland, France, Denmark, Germany, Ireland, Italy, Japan, Netherlands, New Zealand, Norway, Spain, Sweden, Switzerland, the United Kingdom, and the United States.
} 
to GDP, the trade-weighted real exchange rate, world GDP, world prices, real house prices, real credit to the private sector, and real residential investment. World variables are constructed using country-specific trade weights to account for different geographic exposures. They are included to control for the state of the global economy.

The first nine variables are included to help with identification. The last three variables capture developments in the housing market. While mortgage credit would be preferable to total private credit, it is not available for the whole sample of countries.

The model includes both short-term and long-term interest rates. For the countries in our sample, short-term interest rates are largely controlled by central banks. Movements in nominal short-term interest rates are commonly used in VARs to identify monetary policy shocks. Longterm interest rates, on the other hand, tend to be driven by financial market outcomes. As a result, one would expect to observe the effect of capital inflows shocks on long-term rather than on short-term interest rates.

We follow a large literature in monetary economics — see, for example, Christiano, Eichenbaum and Evans (1999) — and include all variables in levels. Apart from interest rates, all variables are in $\log .^{3}$

The data sources are the OECD Economic Outlook, the IMF International Financial Statistics (IFS), and the BIS Macro database. Trade-weighted world variables are constructed using the data in Pesaran, Schuermann and Smith (2009) and trade data from the IMF Direction of Trade Statistics. The variables and data sources are listed in Table 1. The model is estimated with two lags ${ }^{4}$ using quarterly data over the period of the Great Moderation from 1984Q1 to 2006Q4. The high inflation period from the late 1970s to the early 1980s and the recent financial crisis are therefore excluded.

\subsection{Empirical Model}

The model has the following reduced form representation:

$$
Y_{i, t}=C_{i}+\sum_{k=1}^{L} A_{i, k} Y_{i, t-k}+u_{i t} \quad t=1, \ldots T \quad i=1, \ldots, N \quad u_{i, t} \sim N\left(0, \Sigma_{i t}\right)
$$

where $Y_{i, t}$ is a $q \times 1$ vector of explanatory variables, $C_{i}$ is a $q \times 1$ vector of country-specific intercepts, $A_{i, k}$ is a $q \times q$ matrix of autoregressive coefficients up to lag $L$, and $u_{i t}$ is the $q \times 1$ vector of one-step-ahead prediction errors, normally distributed with a $q \times q$ covariance matrix $\Sigma$. Indices $i$ and $t$ indicate that the coefficients are allowed to vary across countries and time.

\footnotetext{
${ }^{3}$ Canova (2005) suggests that, if there is uncertainty on whether the variables in the VAR are stationary, the best solution is to include potentially non-stationary variables in levels. Sims, Stock and Watson (1990) show that in the presence of non-stationarity OLS estimates are super-consistent. Sims (1988) shows that Bayesian inference with a standard Normal-Wishart prior is not affected by non-stationarity.

${ }^{4}$ Hannan Quinn and Schwarz Information Criteria suggest a lag length between one and two for individual countries. We follow Calza et al. (2009) and choose a lag length of two. We obtain similar results when using one or three lags instead.
} 
It is useful to write the model in recursive form:

$$
J_{i, t} Y_{i, t}=\tilde{C}_{i}+\sum_{k=1}^{L} \tilde{A}_{i, k} Y_{i, t-k}+\tilde{u}_{i t} \quad t=1, \ldots T \quad i=1, \ldots, N \quad \tilde{u}_{i, t} \sim N(0, \tilde{\Sigma}),
$$

where $J_{i}$ is a lower triangular $q \times q$ matrix with ones on the main diagonal, $\tilde{C}_{i}=J_{i} C_{i,}, \tilde{A}_{i t, k}=$ $J_{i, t} A_{i t, k}$ for $k=1, \ldots, L, \tilde{u}_{i}=J_{i} u_{i}$, and $\tilde{\Sigma}=J_{i, t} \Sigma_{i t} J_{i, t}^{\prime}$ is a diagonal matrix. By estimating the model in recursive form, we allow for variation in contemporaneous correlation of variables across countries.

\subsubsection{Baseline Model}

Using a panel rather than a single country framework increases the number of observations and leads to more precise estimates. However, transmission mechanisms are likely to vary across countries, for example due to differences in institutional arrangements. We assume that both the intercept and slope coefficients can vary across countries: $\tilde{C}_{i}=\bar{C}+\varepsilon_{i, 0}, \tilde{A}_{i, k}=\bar{A}_{k}+\varepsilon_{i, k}$, where $\bar{C}$ and $\bar{A}_{k}$ are the cross-sectional averages and $\varepsilon_{i, 0}$ and $\varepsilon_{i, k}$ capture country-specific variation.

Pesaran and Smith (1995) show that the standard fixed effects estimator, which only allows for heterogeneous intercepts but imposes homogeneous slopes, is inconsistent in dynamic panels if there is also slope heterogeneity. Applying the fixed effects estimator leads to serial correlation in the residuals. A combination of serially correlated residuals and regressors will therefore lead to biased estimates. Pesaran and Smith (1995) propose the mean group estimator as a solution to this problem. We implement this estimator by interacting all variables with country dummies $D_{i, k}$ for $i=1, \ldots, N$. This procedure amounts to a generalized version of the standard fixed effects estimator that adds fixed effects on the slope coefficients in addition to fixed effects on the intercepts. The interacted country dummies capture all country-specific time-invariant variation $\varepsilon_{i, k}=D_{i, k}$. We begin our empirical analysis by looking at the impulse responses implied by the estimated average coefficients, which can be interpreted as the responses of a typical OECD country.

\subsubsection{Cross-sectional Heterogeneity in Mortgage Market Structure}

As a next step we investigate the effect of the mortgage market structure on the transmission of shocks. As documented in IMF (2008) there is substantial heterogeneity in mortgage market development across countries. While in Anglo-Saxon and Nordic countries deregulation of mortgage markets was relatively rapid and was completed by the mid-1980s, in Japan and continental Europe the process was more gradual.

In more developed mortgage markets consumers should have easier access to credit because of stronger competition and a greater variety of funding sources and loan products. We use the index constructed in IMF (2008) as a summary measure for a number of variables that characterize mortgage market development. The index takes a high value if typical loan-to-value ratios are high, there is the possibility of mortgage equity withdrawal (i.e. consumers can borrow against the 
value of their houses to finance spending), households are able to refinance their mortgages without paying fees, secondary mortgage markets exist, and mortgage contracts are predominantly longterm. Because of limited data availability the index is time-invariant and refers to the mid-2000s. In the next section we adapt the model to look at the effect of a time-varying measure of mortgage market structure.

We use this index to split countries into two groups: one group with highly developed mortgage markets (HDM) and another with less developed mortgage markets (LDM). ${ }^{5}$ Figure 2 shows that the Anglo-Saxon and Nordic countries tend to have a highly developed mortgage market, whereas most countries in continental Europe are in the less developed group. ${ }^{6}$ In the baseline analysis we work with the overall index. To assess the robustness of the results, we then look at some of its subcomponents, splitting countries according to the typical loan-to-value ratio and the possibility of mortgage equity withdrawal. As an alternative to the IMF index, we also split countries using the ratio of mortgage debt to GDP in 2004 taken from the tables in Calza et al (2009). The resulting country groups are listed in Table 2.

Some of the indicators used to construct the mortgage market index, for example loan-tovalue ratios, tend to vary over the business cycle and are likely to respond to economic shocks. This could be a problem for our approach, since we assume that mortgage market characteristics are structural factors and are invariant to the business cycle. Note, however, that our results use only cross-sectional variation, not time-series variation, and are therefore not subject to this critique. Other indicators, such as the possibility of mortgage equity withdrawal, are slow-moving institutional variables and are not likely to be affected by business cycle fluctuations.

The effect of time-invariant features of the mortgage market on the dynamics is fully captured by the country-specific variation $\varepsilon_{i, k}$ in the VAR coefficients. Let $\varepsilon_{i, k}=$ mor $_{i, k}+\eta_{i, k}$ where mor $_{i, k}$ stands for the effects of country specific variation in the mortgage market and $\eta_{i, k}$ for other differences unrelated to the mortgage market. Because $\eta_{i, k}$ has mean zero by assumption, the effects of mortgage market development can then be estimated by computing the average coefficient for the highly developed and the less developed markets separately: $\operatorname{mor}_{H D M, k},=\frac{1}{N_{H D M}} \sum_{i \in H D M} \varepsilon_{i, k}$ and $\operatorname{mor}_{L D M, k}=\frac{1}{N_{L D M}} \sum_{i \in L D M} \varepsilon_{i, k}$. We can interpret the impulse responses implied by the VAR coefficient matrices $\tilde{A}_{i, k H D M, k}=\bar{A}_{k}+\operatorname{mor}_{H D M, k}$ and $\tilde{A}_{i, k L D M, k}=\bar{A}_{k}+\operatorname{mor}_{L D M, k}$ for $k=1, \ldots, L$ as the responses in a typical country with a more developed market and in a typical country with a less developed market.

\footnotetext{
${ }^{5}$ For Switzerland we use the value calculated by Assenmacher-Wesche and Gerlach (2010). Because the index is not available for New Zealand, this country is excluded from the sample.

${ }^{6}$ We split the sample at the median value. Attributing Finland (the country with the median value) to the highly developed group or excluding it from the sample does not affect our results. Our results are also qualitatively robust if several high mortgage market development countries close to the median value of the index are attributed to the low mortgage market development group and vice versa.
} 


\subsubsection{Securitization and Time-varying Financial Structure}

A major development in mortgage finance in the past twenty five years has been the increased availability of mortgage-backed securities (MBS) through changes in legislation in a number of countries. Hoffmann and Nitschka (2009) construct a qualitative de jure indicator for the degree securitization in the mortgage sector. ${ }^{7}$ To exploit this variation we follow the approach of Towbin and Weber (2010) and augment the VAR with an interaction term. To estimate the effect of securitization on the transmission mechanism we interact all variables with the securitization index and generalize our model to:

$$
J_{i t} Y_{i, t}=\tilde{C}_{i t}+\sum_{k=1}^{L} \tilde{A}_{i t, k} Y_{i, t-k}+\tilde{u}_{i t} \quad t=1, \ldots T \quad i=1, \ldots, N \quad \tilde{u}_{i t} \sim N(0, \tilde{\Sigma})
$$

where $\tilde{A}_{i t, k}=D_{i k}^{0}+D_{k}^{1} M B S_{i, t}+\varepsilon_{i, k}$, and $M B S_{i, t}$ stands for the securitization index. Equivalent definitions hold for the lower triangular matrix $J_{i t}$ and the intercept $\tilde{C}_{i t}$. The effect of securitization on the regression coefficients $\left(D_{k}^{1}\right)$ is assumed to be homogenous across countries, while $D_{i k}^{0}$ is country specific.

We can compute impulse responses for a typical country with a high degree of securitization and coefficient matrix $\tilde{A}_{H M B S, k}=D_{i k}^{0}+D_{k}^{1} M B S_{H I G H}$ and a typical country with a low degree of securitization and coefficient matrix $A_{L M B S, k}=D_{i k}^{0}+D_{k}^{1} M B S_{L O W}$. Apart from its effect on the dynamics, securitization may also have a permanent effect on the level of variables. To control for such an effect, we also include the index in levels.

The securitization index equals one if countries have a fully liberalized MBS market and zero if no securitization is allowed. If a limited degree of securitization is allowed the index takes the value 0.3. The data is at quarterly frequency and covers the period from 1985Q1 to 2008Q1. In the United States mortgage-backed securities have been allowed during the whole sample period. In Australia, Canada, Ireland, Netherlands, Spain and the United Kingdom they have become widely available after major mortgage market reforms during the sample period. Whereas a limited form of securitization has existed in Switzerland, Germany, and Sweden for a long time, liberalization has led to an intermediate degree of securitization in Finland, France, and New Zealand. In Denmark, Italy, Japan, Belgium, and Norway securitization has not been introduced. ${ }^{8}$ If securitization affects the transmission of monetary policy shocks and capital inflows shocks, we expect to see variation in the VAR coefficients over time.

\footnotetext{
${ }^{7}$ We would expect the degree of securitization to be endogenous to developments in the housing market. When the housing market is booming the probability of mortgage default is low and there is high demand for MBS. When real house prices decline, on the other hand, borrowers' default probabilities increase and become correlated and MBS lose liquidity as a result. Because the indicator constructed by Hoffman and Nitschka is a de jure indicator, it reflects insitutional changes in the ability to securitize assets and is not likely to suffer from endogeneity.

${ }^{8}$ The dataset constructed in Hoffmann and Nitschka (2009) has no information for New Zealand and Ireland. Based on our own research, we constructed additional time series on the degree of securitization in these two countries. New Zealand has allowed a a limited degree of securitization in 1996 (Brady (1998)). The index takes a value of 0 until 1995Q4 and a value of 0.3 afterwards. For Ireland, the index is zero until 1995Q4 and takes the value one therafter (Addison-Smyth et al (2009)).
} 


\subsection{Identification}

We identify two types of shocks that lead to lower domestic interest rates: an expansionary monetary policy shock and a capital inflows shock. The two shocks are identified using the sign restrictions approach developed by Canova and de Nicoló (2002), Faust and Rogers (2003), and Uhlig (2005).

We can think of the one step ahead prediction error $u_{t}$ as a linear combination of orthonormal structural shocks $u_{t}=B v_{t}$, with $E\left(v_{t}^{\prime} v_{t}\right)=I$. The only restriction on $B$ comes from the covariance matrix of the prediction errors $\Sigma=E\left(u_{t} u_{t}^{\prime}\right)=E\left(B v_{t} v_{t}^{\prime} B^{\prime}\right)=B B^{\prime}$. This leaves many degrees of freedom in specifying $B$ and further restrictions are necessary to achieve identification. The challenge for structural VAR models is to find credible restrictions on $B$. Sign restrictions narrow down the set of acceptable $B$ by restricting the sign of the impulse responses of a set of variables to a structural shock.

Table 3 lists the sign restrictions used to identify capital inflows and monetary policy shocks. They are similar to the ones in Sá and Wieladek (2010) and rely on previous theoretical and empirical work. We do not impose any restrictions on the housing variables, which are our main variables of interest. Following Uhlig (2005), the restrictions are imposed for four quarters after the shock.

Positive capital inflows shocks lead to an increase in the current account deficit, a decrease in the long term interest rate, an appreciation of the real exchange rate, and an increase in consumption and non-residential investment. The restrictions are consistent with the regularities of capital inflow periods identified in Reinhart and Reinhart (2008). We understand a capital inflows shock to be an unexpected increase in foreigners' demand for domestic assets.

Open economy models deliver a number of reasons why foreigners may increase their demand for domestic assets. For example, a global increase in savings would increase demand for assets in general and therefore also lower the domestic ex ante real interest rate. Domestic residents dissave and consume more, while investment rises, leading to a real exchange rate appreciation and a current account deficit. Another possibility is a reshuffling of foreigners' portfolios towards domestic assets as in Sá and Viani (2010) and Caballero et al. (2008). Such a shift may happen because of changes in the portfolio preferences of foreign investors, foreign financial market structure or a domestic financial reform, all of which make it more attractive for foreigners to invest in domestic assets. Again, the portfolio shift towards domestic assets leads to a capital inflow that finances consumption and investment, lowers real domestic interest rates and appreciates the domestic currency. Finally, foreign monetary authorities may attempt to improve competitiveness through expansionary monetary policy. Low foreign interest rates make domestic assets more attractive, capital inflows drive down the domestic real interest rate, and the real exchange rate appreciates.

Although the sources of these events are quite distinct, we argue that the consequences for the domestic economy and in particular the housing sector should be similar. In all cases, lower domestic real interest rates should lead to an expansion in domestic credit and spur housing activity.

We restrict the real long term interest rate rather than the nominal rate because real shifts in the total demand for domestic assets should affect real returns. The restriction is on the long rate 
as opposed to the short rate because a broad class of models assumes that the central bank perfectly controls the short rate. In order to compute the ex ante real long term interest rate we need to subtract expected inflation from the nominal rate. Our measure for expected inflation is the VAR forecast. We implement the sign restriction on the real long rate by computing the response of the nominal long rate and the price level in a first step. We then use the response of the price level to compute the response of the (annualized) ten year inflation and subtract the inflation response from the response of the nominal long term rate to compute the response of the ex ante real rate. ${ }^{9}$

Our assumption regarding the behavior of the long term interest rate is crucial to distinguish capital inflows shocks from other shocks that generate a real appreciation and a current account deficit. Consider a small open economy with nontraded goods and imperfect substitutability between domestic and foreign assets. An aggregate demand shock (public or private) would lead to a real appreciation (because of higher demand for nontraded goods) and a current account deficit, but to an increase in the real interest rate. Without the restriction on the long rate, the shock could be observationally equivalent to a capital inflows shock. In standard models, transitory productivity shocks generate a current account surplus because people save a large fraction of their temporary income increase. The current account behavior is inconsistent with our sign restrictions for capital inflows shocks. However, a permanent increase in the total factor productivity will lead to a current account deficit. The shock increases the marginal productivity of capital, making investment in the domestic economy more attractive. Since the increase is permanent and the consumption smoothing motive disappears, savings will not rise. Therefore, there is a net capital inflow into the domestic economy and the exchange rate appreciates, just as with capital inflows shocks. A permanent increase in productivity leads, however, to an increase in the domestic real interest rate because the marginal productivity of capital increases and imperfect substitutability between assets impedes exact interest rate parity. Hence, the sign restriction on the long rate allows us to distinguish a permanent productivity shock from a capital inflows shock. ${ }^{10}$

Our identification restrictions for monetary policy shocks rely on a large literature surveyed in Christiano, Eichenbaum and Evans (1999). An expansionary monetary policy shock decreases the nominal short term interest rate, leads to an increase in prices, consumption and non residential investment and to a real depreciation. This is consistent with the sign restrictions derived theoretically in Canova and de Nicoló (2002). They show that, under a variety of different models, output and prices rise following an expansionary monetary policy shock. The restriction on the exchange rate follows from a simple Mundell Fleming model: lower interest rates decrease the demand for domestic financial assets and lead to a depreciation of the nominal and (in a sticky price environment) the real exchange rate. This restriction follows from uncovered interest rate parity, for which empirical support is limited. It should be noted, however, that the restriction is only on

\footnotetext{
${ }^{9}$ Restricting the response of the real or nominal short term interest rate yields very similar results.

${ }^{10} \mathrm{It}$ is theoretically possible that the central bank cuts the nominal rate aggressively to fight the deflationary pressures that arise from the increase in productivity. This can also lead to a fall in the real rate, at least at shorter horizons. In that case, however, a permanent productivity shock will still have a permanent effect on the real exchange rate. Our empirical results indicate no permanent effect on the real exchange rate, which is inconsistent with a permanent productivity shock.
} 
the sign and not the exact magnitude of the exchange rate movement. There is broad empirical support that the exchange rate depreciates after an expansionary monetary policy shock — see, for example, Eichenbaum and Evans (1995), Forni and Gambetti (2010), Scholl and Uhlig (2008) and Zettelmeyer (2004). ${ }^{11}$

A common alternative to sign restrictions is the Choleski decomposition, which assumes a lower triangular structure for $B$. This corresponds to imposing zero restrictions on the contemporaneous interactions between variables. To identify a monetary policy shock the set of explanatory variables must be split into two groups: a group of variables that do not respond contemporaneously to the short term interest rate but to which the short rate reacts; and a group of variables that react contemporaneously to changes in the short rate but have no immediate effect on the short rate. A number of studies use the Choleski decomposition to analyze the effect of monetary policy shocks on the housing sector - for example, Assenmacher-Wesche and Gerlach (2010) and Calza, Monacelli, and Straca (2009). A Choleski decomposition often forces researchers to impose more zero restrictions on contemporaneous relations than delivered by theory. The ordering of asset prices and credit with respect to the short term interest rate is especially problematic. Sign restrictions provide a means to check the robustness of these studies by using less restrictive identification assumptions. In order to allow for a potential zero response of consumption, non-residential investment and prices, we impose the sign restrictions only after the first quarter.

\subsection{Inference}

Following Uhlig (2005) we compute Bayesian error bands. Our error bands capture two types of uncertainty: parameter uncertainty and identification uncertainty. Uncertainty about the true parameters $A_{i, k}$ and $\Sigma$ follows from a limited number of observations and appears in all SVAR models. For SVARs that use exact short or long run restrictions there is no identification uncertainty: given $\Sigma$ and $A_{i, k}$, there is a unique $B$ that satisfies the identification restrictions. With sign restrictions there is a set of $B$ matrices that satisfy the sign restrictions. Identification is inexact and there is additional uncertainty about the correct identification scheme. Using an approach similar to Paustian (2007) we separate identification and parameter uncertainty.

To account for parameter uncertainty we use an uninformative Normal-Wishart prior. We draw all parameters jointly from the posterior (including the coefficients on the interaction terms). We start from the recursive model (2). Since the covariance matrix $\tilde{\Sigma}$ is diagonal by construction, we can proceed equation by equation. Given a parameter draw $d$, we then evaluate the coefficient for the country type we are interested in. For example, for a country with high prevalence of mortgagebacked securities we compute $\tilde{A}_{H M B S, k}^{d}=D_{i k}^{0 d}+D_{k}^{1 d} M B S_{H I G H}$, given draws $D_{i k}^{0 d}$ and $D_{k}^{1 d}$. As in Cogley and Sargent (2005) we impose the prior that responses are not explosive and discard

\footnotetext{
${ }^{11}$ An unresolved issue is whether "delayed overshooting" occurs. Eichenbaum and Evans (1995) and Scholl and Uhlig (2008) find that the exchange rate continues to depreciate for a few periods after the monetary policy shock, which is in contradiction to Dornbusch's (1976) overshooting model. Forni and Gambetti (2010) use structural dynamic factor models and show that delayed overshooting disappears once a sufficient amount of economic information is included in the model.
} 
explosive draws. With the posterior draws for $\tilde{A}_{i t, k}^{d}$ and $\tilde{\Sigma}^{d}$, we can then compute the reduced form parameters $A_{i t, k}^{d}$ and $\Sigma_{i t}^{d}$, using the expressions of section 3.2. Since matrix $\tilde{A}_{i t, k}$ can vary with mortgage market characteristics, this implies that the covariance matrix $\Sigma_{i t}=\tilde{A}_{i t, k} \tilde{\Sigma}^{\tilde{\Sigma}} \tilde{A}_{i t, k}^{\prime}$ also depends on mortgage market characteristics, whereas starting from the reduced form specification implies a constant covariance matrix. ${ }^{12}$

For a given parameter draw, we then account for identification uncertainty and compute the set of $B$ matrices that satisfies the sign restrictions. Let $\tilde{B}_{d}$ be an orthogonal factorization, e.g. the Choleski decomposition, of the posterior draw of the covariance matrix $\Sigma_{d}$, with $\tilde{B}_{d} \tilde{B}_{d}^{\prime}=\Sigma_{d}$. Multiplying $\tilde{B}_{d}$ with orthonormal matrix $Q, B_{d}=\tilde{B}_{d} Q$, will generate another decomposition of $\Sigma_{d}: B_{d} B_{d}^{\prime}=\tilde{B}_{d} Q Q^{\prime} \tilde{B}_{d}^{\prime}$. Following Rubio-Ramirez, Waggoner, and Zha (2009) we compute $Q$ by drawing an independent standard normal $q \times q$ matrix $X$ and apply the QR decomposition $X=Q R$. We keep the draw if $B_{d}$ generates impulse responses that satisfy the sign restrictions for both shocks. For a given parameter draw, we repeatedly draw $Q$ until we have found 100 matrices that satisfy the sign restrictions. We save the point wise median and 16th and 84 th percentiles of the impulse response distribution generated by accepted matrices $B_{d}$.

We repeat this exercise for 100 parameter draws and save median, upper, and lower percentile for each parameter draw. This gives us 100 different estimates of the median, the lower, and the upper percentile. The first statistic focuses on the distribution of all medians. We report the median of all medians and, as error bands, the 16th and 84th percentile of the distribution. In this case the error bands account for parameter uncertainty and reflect the uncertainty about the true median that comes from limited sample size. As a second statistic we report the median of the lower and upper percentile across all parameter draws. In this case the error bands reflect identification uncertainty.

In comparison to our approach, error bands reported in Uhlig (2005) reflect both parameter and identification uncertainty. Separating identification and parameter uncertainty can provide useful additional information. The type of uncertainty that should be taken under consideration in constructing error bands depends on the question being asked. If the question is whether we can confidently say that the response of house prices to a capital inflows shocks is positive, we should account for both parameter and identification uncertainty. We have to consider both the fact that we have only a limited amount of data (which leads to parameter uncertainty) and limited information on the properties of the structural shocks (which leads to identification uncertainty). But if the question is whether impulse responses differ between countries with high and low mortgage market development, we should focus on parameter uncertainty. This is because structural mortgage market

\footnotetext{
${ }^{12}$ In principle, the posterior of reduced form $A_{i t, k}$ and $\Sigma_{i t}$ will depend on the ordering of the variables in the recursive VAR. Our specification orders world output and prices first, followed by domestic variables ordered as in the data section. A related issue arises in a stochastically time-varying structural VAR as discussed in Primiceri (2005). Primiceri notes that the problem could be resolved by estimating the model with several orderings. We have experimented with this and our results were not quantitatively sensitive to the ordering. Even a model that starts from the reduced form specification and keeps the covariance matrix of the forecast error constant gave very similar results. Identification based on sign restrictions that cover multiple horizons is also less sensitive to the estimate of the covariance matrix than identification based on short run restrictions, since the set of accepted impulse responses also depends on the autoregressive coefficients.
} 
differences between the two types of countries will be reflected in differences in parameters rather than identification. We are interested whether the distribution of accepted impulse responses shifts and a central parameter of the distribution is its median. The confidence with which we can say that the distribution of medians differs between the two types of countries depends on how precise the estimates are, which relates to parameter uncertainty. When comparing medians for two types of countries, we account for potential correlation between the median estimates and compute the medians with the same parameter draws. ${ }^{13}$

To ensure comparability of impulse responses, we normalize the size of the shocks to one standard deviation based on the corresponding covariance matrix of forecast errors. Normalizing with respect to the size of the shock seems preferable to normalizing with respect to the response of a given variable. While for monetary policy shocks normalizing with respect to the short term interest rate may seem natural - for example, a fall by 25 basis points - it is not obvious what variable should be normalized for a capital inflows shock. Normalizing the size of a shock to one standard deviation is equivalent to normalizing with respect to the probability of the event, since under normality a one standard deviation shock implies that events are smaller in absolute size in $68 \%$ of the cases. This facilitates the comparison of capital inflows and monetary policy shocks and the comparison across different mortgage market structures.

Note that, since our estimate of the covariance matrix varies with mortgage market characteristics, if we observe a larger increase in house prices in countries with more developed mortgage markets we cannot conclude that the structure of the mortgage market is amplifying the shocks. It may simply be the case that the one standard deviation normalization produces shocks of a larger magnitude for the group of countries with more developed mortgage markets. We therefore report also the responses of non-housing variables across groups of countries with different mortgage market structures. If the response of non-housing variables is broadly the same, we consider it more likely that we are comparing shocks of similar sizes and that differences in the response of housing variables stem from an amplification effect.

\section{Results}

\subsection{The Effects of Capital Inflows and Monetary Policy Shocks on Housing Variables}

Figures 3 and 4 show the impulse response functions over 40 quarters for a one standard deviation capital inflows and monetary policy shock. We plot the median (solid blue line) and the 16th and 84th percentiles that account for parameter uncertainty (dashed red lines) and identification

\footnotetext{
${ }^{13}$ Uhlig (2005) proposes as an alternative to the pure sign restriction approach where error bands only reflect parameter uncertainty. The approach chooses the orthogonal factorization that minimizes a penalty function that penalizes wrong sign and rewards correct signs of impulse responses. To identify a unique decomposition the penalty function rewards strong responses with the correct sign more than weak responses with the correct sign. A disadvantage is that we lose the information about identification uncertainty and the choice of the penalty function is arbitrary. The reward of strong responses also tends to make the selected responses larger than the median.
} 
uncertainty (dotted black lines). The grey shaded area indicates the variables and the horizon for which sign restrictions are imposed.

At the median a capital inflows shock leads on impact to a current account deficit of about $0.2 \%$ of GDP, the long rate falls by about 11 basis points and the real effective exchange rate appreciates by about $0.8 \%$. Consumption peaks at $0.2 \%$ after six quarters and non-residential rises quickly by about $0.8 \%$. The responses of world output and world prices are of very small magnitude, in line with the relatively small size of an average OECD country. We do not discuss the response of world variables in detail, but consider them as pure controls for external events.

A capital inflows shock leads to an expansion of the housing sector. There is a persistent rise in real private credit and house prices that in both cases peak after seven quarters at about $0.5 \%$ and $0.6 \%$, before slowly reverting back to zero. The response of residential investment is quicker and more short-lived, peaking at $0.7 \%$ after two quarters. Error bands indicate that the responses for all housing sector variables are statistically significant. The price level initially falls by about $0.05 \%$ before beginning to rise after about a year. The deflationary pressures may arise either because a nominal appreciation lowers the domestic currency prices of imports or as a result of an inflow of cheap imports. The nominal short rate falls by about the same amount as the long rate (10 basis points), keeping the term spread initially constant. The short rate then starts to rise and peaks at 8 basis points after ten quarters. The shape of the response is consistent with a central bank that reacts to the fall in prices by lowering policy interest rates and then starts raising them again as inflation resumes. If we assume that central banks do not have full control over the short rate, an alternative explanation is that capital inflows affect the term structure at all maturities by about the same amount.

A monetary policy shock leads to a fall in the short rate by 25 basis points. The long rate falls by only 10 basis points and the term spread therefore rises. We observe a permanent increase in the price level of about $0.1 \%$. Consumption rises to about $0.2 \%$ above trend after six quarters and falls slowly back to its long term value. The hump shaped response of consumption and its timing are consistent with previous studies that document the effects of monetary policy shocks in VARs. ${ }^{14}$ Non-residential investment increases on impact by about $0.6 \%$ and reverts back afterwards. The real exchange rate depreciates initially by about $0.4 \%$ and then appreciates slowly back to its long run value with a slight delay in overshooting, which is broadly consistent with Dornbusch's overshooting model. The current account does not move, possibly because the gain in competitiveness from an exchange rate depreciation is compensated by stronger demand for imports. The shape of the response of housing variables to the monetary policy shock is similar to the capital inflows shock, but the size of the response is smaller. Real credit and house prices peak at about $0.3 \%$ after ten quarters. Real residential investment peaks at $0.2 \%$. For all three housing variables, zero lies outside the identification uncertainty error bands at some point, but at short horizons the bands are wide.

Table 4 shows the forecast error variance decomposition. At the median, capital inflows shocks

\footnotetext{
${ }^{14}$ See Christiano, Eichenbaum and Evans (1999) for a survey.
} 
explain up to $14 \%$ of the variance in real credit and $12 \%$ of the variance in house prices and residential investment at longer forecast horizons. By contrast, monetary policy shocks explain only up to $8 \%$ of the variance of real credit, $6 \%$ of the variance in house prices and $5 \%$ of the variance in residential investment. These results are consistent with Sá and Wieladek (2010) who find that, for the United States, capital inflows shocks explain a substantially larger fraction of the variance in house prices than monetary policy shocks.

\subsection{The Role of Cross-Sectional Variation in Mortgage Market Development}

We use the index of mortgage market development in IMF (2008) to split countries into two groups: a group with more developed mortgage markets and a group with less developed mortgage markets. Figures 5 and 6 compare median impulse responses of housing variables for the two groups and Figures 7 and 8 compare responses of non housing variables. Error bands reflect parameter uncertainty.

Mortgage market development affects the transmission of monetary policy shocks: in a highly developed mortgage market the rise in real residential investment peaks at about $0.5 \%$, compared to a zero response in a low developed market. Real house prices increase by more than $0.4 \%$ after ten quarters in a more developed market, compared to a very muted response in a less developed market. The peak response of real private credit in a highly developed market at $0.4 \%$ is about double the response in a less developed market. These differences are statistically significant for all three variables, but only marginally so for private credit.

The differences in the responses to monetary policy shocks across the two groups of countries are concentrated on housing variables, supporting the view that the IMF index captures housingspecific heterogeneity. There are no significant differences on impact in the responses of consumption and non-residential investment, but in countries with a liberalized mortgage market the responses are somewhat more persistent (Figure 8). The increased persistence may arise because of secondround effects from an increase in housing activity. We also do not find substantial differences in the responses of other non-housing variables, such as interest rates or the real exchange rate, suggesting that the stronger effect in a liberalized market stems from amplification in the transmission of the shock rather than from a larger shock.

Capital inflows shocks also have a greater effect on housing variables in countries with higher mortgage market development (Figure 5). The responses of real house prices and residential investment are clearly stronger and the differences are statistically significant. The response of real private credit has a similar magnitude in both groups of countries, but is more persistent in countries with more developed mortgage markets. Regarding the responses of non-housing variables (Figure 7), we observe a stronger response of consumption in countries with more developed mortgage markets, possibly because of a wealth effect through higher house prices. As for monetary

policy shocks, the response of non-residential investment is more persistent in countries with more developed mortgage markets, but there are no differences at short horizons. There are also no notable differences in the responses of other non-housing variables. 
Table 4 shows that the share of the forecast error variance of the three housing variables that can be explained by monetary and capital inflows shocks tends to be slightly higher in the group of countries with a more developed mortgage market.

Our results indicate that capital flows and monetary policy shocks have a stronger effect on housing variables in more developed mortgage markets and are consistent with a role for the financial accelerator. In highly developed mortgage markets households can pledge a larger fraction of their house as collateral, which results in higher leverage. If households are highly indebted, they are more sensitive to changes in interest rates because small changes in rates can have a large effect on their ability to service the debt. As a result, housing demand becomes more sensitive to interest rates.

\subsection{The Role of Securitization and Time-varying Financial Structure}

Figures 9 and 10 compare the impulse responses of housing variables in countries with a high and a low prevalence of mortgage-backed securities. We evaluate the reduced form coefficients at values $M B S_{H I G H}=0.75$ and $M B S_{L O W}=0.25$, on a scale from 0 to 1 and report the median impulse response with error bands that account for parameter uncertainty. A high value of the index indicates that mortgage-backed securitization is permitted, while a low value indicates that securitization is restricted.

Capital inflows shocks have a larger and more persistent effect in countries that allow for mortgage-backed securities. In a country with a high MBS index the response of real private credit peaks at $0.8 \%$, which is approximately two times stronger than in a country with a low MBS index. A high value of the MBS index also amplifies the responses of real residential investment and house prices by a factor of about 2 . The differences are statistically significant for all three variables.

The amplifying effect of mortgage-backed securities on housing variables is also reflected in the forecast error variance decomposition, reported in Table 4. Capital inflows shocks explain about $17 \%$ of the variation in real credit at the ten year horizon in countries with high levels of securitization, compared to about $11 \%$ in countries with low levels of securitization. For real house prices, the fraction is $17 \%$ in high securitization countries versus $10 \%$ in low securitization countries. For real residential investment the fraction is $17 \%$ versus $9 \%$.

Securitization also amplifies monetary policy shocks, but to a smaller degree. In countries with a high MBS index the effect of monetary policy shocks on real residential investment peaks at $0.4 \%$ compared with $0.2 \%$ in countries with a low MBS index. The peak responses of house prices is about $0.1 \%$ higher in countries where mortgage-backed securitization is more prevalent. Both differences are statistically significant, but only for a short horizon. There is no notable difference in the response of credit.

In terms of forecast error variance decompositions, reported in Table 4, there is no evidence that the contribution of monetary policy shocks is larger in countries that have mortgage-backed securities. The fraction of the variance in the housing variables explained by monetary policy shocks 
is even somewhat smaller in countries with high prevalence of MBS. In countries with high levels of securitization monetary policy shocks explain between $4 \%$ and $5 \%$ of the variation in credit, house prices and residential investment at long horizons. This compares with fractions between $6 \%$ and $9 \%$ in countries with low levels of securitization.

The finding that securitization amplifies the effects of both shocks is again consistent with the presence of a financial accelerator mechanism. If we assume that securitization increases the efficiency of the financial system and allows households to be more leveraged, the effect of interest rate changes on the housing market should increase. The results are also consistent with the argument in Rajan (2005) that securitization allowed banks to take more risk and made them more sensitive to changes in interest rates. It does not automatically follow from these explanations that the amplification effect of securitization should be stronger for capital inflows shocks than for monetary policy shocks. One reason for this, suggested by Diamond and Rajan (2009), is that securitization allows international investors to invest directly in mortgage debt. Securitization packages mortgages together and slices them in different levels of risk. The riskiest tranches can be bought by investors with higher risk appetite, while the AAA tranches can be sold to international investors who look for safe assets. In this way, securitization increases the share of foreign capital inflows allocated to home mortgage loans, amplifying the effects of capital inflows on the domestic housing market.

Figures 11 and 12 report the differences in the responses of non-housing variables. The response of consumption to a capital inflows shock is about $0.15 \%$ stronger in countries with high levels of securitization, again consistent with a wealth effect through higher house prices. The rise in nonresidential investment is somewhat smaller on impact in securitized countries, but is more persistent. There are also some differences in the response of the other variables. For example, the reaction of the current account and the long term interest rate is stronger and more persistent in securitized countries. This may indicate that part of the stronger response of housing variables comes from a change in the response of these other variables. For monetary policy shocks, however, the responses of non-housing variables is similar in countries with high and low securitization.

\section{Robustness}

\subsection{Changes in the Sample Period}

A major limitation of the index of mortgage market development constructed in IMF (2008) is that it does not vary over time. In Anglo-Saxon and Nordic countries deregulation of mortgage markets was relatively rapid and largely completed by the mid-1980s. Because our sample starts in 1984, it would capture the period post-deregulation in these countries. However, in Japan and continental Europe the process was more gradual.

To check whether our results are affected by structural changes in the degree of mortgage market regulation, we estimate the model restricting sample to the period from 1990Q1 to 2006Q4. Table 5 
reports the responses in countries with high and low mortgage market development at the one-year and three-years horizons, together with 16th and 84th percentiles. For comparison, the baseline results for the period from 1984Q1 to 2006Q4 are also reported.

The results for the restricted time period are qualitatively similar but less precise than the baseline results. The reduction in precision is probably due to a smaller number of observations. As before, the responses of the housing variables to both shocks tend to be stronger in countries with a high degree of mortgage market development.

\subsection{Alternative Sample-splitting Criteria}

For further robustness, we also report results for three alternative sample splitting criteria: the ratio of mortgage debt to GDP listed in Calza et al. (2009), the possibility of mortgage equity withdrawal, and the typical loan-to-value ratio. Again, only time-invariant (cross-sectional) information is available for these measures.

The results, reported in Table 6 suggest that housing variables respond more strongly to both shocks in countries that have a higher mortgage to GDP ratio. In all cases the differences have the expected sign and are statistically significant at least at one of the horizons in five out of six cases. In countries that allow for mortgage equity withdrawal all three housing variables respond more strongly to monetary policy and capital inflows shocks. Except for the response of private credit to a capital inflows shock, the difference is significant at one-year or three-years horizons. When we split the sample according to typical loan-to-value ratio, the differences have again the expected sign, but tend to be insignificant.

\subsection{Monetary Unions and Exchange Rate Regimes}

The introduction of the Euro in 1999 and the loss of monetary policy independence by its adopters creates two potential problems for our methodology. The first problem concerns the correct identification of the shocks: part of the identified unexpected movements in interest rates may be forecastable if one accounts for Euro Area fundamentals and are only surprising from a single country's perspective. The second problem concerns the transmission of the shocks, which may be affected by changes in exchange rate regimes (for example, moving from a floating to a fixed exchange rate).

One way to adapt our framework to take into account the adoption of the Euro would be to look at a Euro Area aggregate rather than at individual member countries. We see some important drawbacks with that approach. First, before 1999 member countries had autonomy in the conduct of monetary policy and aggregation would neglect this fact. Second, our analysis has revealed important heterogeneity in the transmission of shocks to the housing sector and aggregation would eliminate this heterogeneity.

Because of these drawbacks with aggregation, we follow previous studies that investigate the transmission of monetary policy shocks - Assenmacher-Wesche and Gerlach (2010), Calza et al. (2009) and Goodhart and Hoffmann (2008) — and treat each country as a separate cross-sectional 
unit. In contrast to these studies, however, our model controls for movements in output and prices in the country's trading partners, often other Euro members. This should help with the identification of monetary policy shocks. In addition, we identify monetary policy shocks using sign restrictions, an approach that is less vulnerable to omitted variable bias than a recursive scheme, since it pins down the sign of the responses of important macroeconomic variables.

To address the second problem - the possibility that the adoption of the Euro may have affected the transmission of shocks - we augment the model by including an exchange rate regime variable as an additional interaction term. The exchange rate regime is captured by an indicator variable that takes a value of one for a peg and zero otherwise and is constructed using the IMF's de jure classification.

Table 7 reports the impulse responses evaluated at a value zero for the indicator variable, i.e., for countries without a peg. ${ }^{15}$ Our main results hold both for the IMF index of mortgage market development and for the securitization index. This suggests that our main conclusions still hold in countries without a peg when we control for the exchange rate regime.

\section{Conclusion}

In this study we examine three different explanations for housing sector booms: monetary policy, capital inflows and financial innovation. We estimate a panel VAR model and identify monetary policy and capital inflows shocks using sign restrictions. To assess whether the structure of the mortgage market affects the transmission of macroeconomic shocks to the housing sector we split the sample into countries with high and low mortgage market development. We also adapt the model to allow the coefficients in the VAR to vary with the degree of securitization.

We find that both capital inflows and monetary policy shocks have a significant and positive effect on real house prices, real credit to the private sector and real residential investment. Housing variables respond more strongly to both shocks in countries with a more developed mortgage market and in countries where securitization is more prevalent. This is consistent with the presence of a financial accelerator mechanism. In highly developed mortgage markets households can pledge a larger fraction of their house as collateral, which results in higher leverage. If households are highly indebted, they are more sensitive to changes in the value of collateral. We find that the propagation effect of securitization is stronger for capital inflows than for monetary policy shocks. The response of housing variables to capital inflows shocks is larger and longer lasting in countries where securitization is allowed. A potential explanation is that mortgage-backed securitization transforms illiquid, low-grade loans into publicly traded assets of higher quality which are attractive to international investors. In this way, securitization increases the share of foreign capital inflows allocated to home mortgage loans, amplifying the effects of capital inflows on the domestic housing market.

\footnotetext{
${ }^{15}$ Impulse responses for countries with a peg were imprecise, although not in contradiction with our results. These responses are available on request.
} 
The run-up to the present crisis was characterized by a housing boom in most OECD countries. Our results suggest that capital inflows coupled with innovations in the mortgage market played an important role in the housing boom. This implies that countries with more developed mortgage markets and a high degree of securitization should be wary of large external imbalances and work towards their reduction. At the same time, improved financial regulation would help reduce the effect of capital inflows on asset prices. 


\section{References}

[1] Addison-Smyth, Diarmaid, Kieran McQuinn and Gerard O'Reilly (2009), 'Modelling Credit in the Irish Mortgage Market'. Central Bank \& Financial Services Authority of Ireland Research Technical Paper

[2] Aizenman, Joshua, and Yothin Jinjarak (2009) 'Current account patterns and national real estate markets'. Journal of Urban Economics 66(2), 75-89

[3] Assenmacher-Wesche, Katrin, and Stefan Gerlach (2010) 'Financial structure and the impact of monetary policy on property prices'. Mimeo, University of Frankfurt

[6] Bernanke, Ben S. (2010) 'Monetary policy and the housing bubble'. Speech at the Annual Meeting of the American Economic Association, Atlanta, Georgia, 3 January

[5] Bernanke, Ben, and Mark Gertler (1989) 'Agency costs, net worth, and business fluctuations'. American Economic Review 79(1), 14-31

[6] Bernanke, Ben S, and Mark Gertler (1995) 'Inside the black box: The credit channel of monetary policy transmission'. Journal of Economic Perspectives 9(4), 27-48

[7] Bernanke, Ben S., Mark Gertler, and Simon Gilchrist (1999) 'The financial accelerator in a quantitative business cycle framework'. In Handbook of Macroeconomics, ed. J. B. Taylor and M. Woodford

[8] Borio, Claudio, and Haibin Zhu (2008) 'Capital regulation, risk-taking and monetary policy: a missing link in the transmission mechanism?' BIS Working Papers 268, Bank for International Settlements, December

[9] Brady, Peter (1998), 'The regulatory framework for securitisation by banks in New Zealand', available at http://www.rbnz.govt.nz/speeches/0060353.html

[10] Caballero, Ricardo J, Emmanuel Farhi, and Pierre-Olivier Gourinchas (2008) 'An equilibrium model of "global imbalances" and low interest rates'. American Economic Review 98(1), 358-93

[11] Calvo, Guillermo A., Leonardo Leiderman, and Carmen M. Reinhart (1994) 'The capital inflows problem: Concepts and issues'. Contemporary Economic Policy 12(3), 54-66

[12] Calza, Alessandro, Tommaso Monacelli, and Livio Stracca (2009) 'Housing finance and monetary policy'. Working Paper Series 1069, European Central Bank, July

[13] Canova, Fabio (2007) Methods for Applied Macroeconomic Research (Princeton University Press)

[14] Canova, Fabio, and Gianni De Nicolo (2002) 'Monetary disturbances matter for business fluctuations in the G-7'. Journal of Monetary Economics 49(6), 1131-1159 
[15] Carstensen, Kai, Oliver Hülsewig, and Timo Wollmershäuser (2009) 'Monetary policy transmission and house prices: European cross-country evidence'. Technical Report

[16] Christiano, Lawrence J., Martin Eichenbaum, and Charles L. Evans (1999) 'Monetary policy shocks: What have we learned and to what end?' In Handbook of Macroeconomics, ed. J. B. Taylor and M. Woodford, vol. 1 of Handbook of Macroeconomics (Elsevier) chapter 2, pp. 65148

[17] Cogley, Timothy, and Thomas J. Sargent (2005) 'Drift and volatilities: Monetary policies and outcomes in the post WWII U.S.' Review of Economic Dynamics 8(2), 262-302

[18] Diamond, Douglas W., and Raghuram G. Rajan (2009) 'The credit crisis: Conjectures about causes and remedies'. American Economic Review 99(2), 606-10

[19] Dornbusch, Rudiger (1976) 'Expectations and exchange rate dynamics'. Journal of Political Economy 84(6), 1161-76

[20] Eichenbaum, Martin, and Charles L Evans (1995) 'Some empirical evidence on the effects of shocks to monetary policy on exchange rates'. The Quarterly Journal of Economics 110(4), 9751009

[21] Faust, Jon, and John H. Rogers (2003) 'Monetary policy's role in exchange rate behavior'. Journal of Monetary Economics 50(7), 1403-1424

[22] Forni, Mario, and Luca Gambetti (2010) 'The dynamic effects of monetary policy: A structural factor model approach'. Journal of Monetary Economics 57(2), 203 - 216

[23] Goodhart, Charles, and Boris Hofmann (2008) 'House prices, money, credit, and the macroeconomy'. Oxford Review of Economic Policy 24(1), 180-205

[24] Hoffmann, Mathias, and Thomas Nitschka (2009) 'Securitization of mortgage debt, asset prices and international risk sharing'. CESifo Working Paper Series, CESifo Group Munich

[25] Hume, Michael, and Andrew Sentance (2009) 'The global credit boom: Challenges for macroeconomics and policy'. Journal of International Money and Finance 28(8), 1426-1461

[26] Iacoviello, Matteo (2005) 'House prices, borrowing constraints, and monetary policy in the business cycle'. American Economic Review 95(3), 739-764

[27] IMF (2008) 'The changing housing cycle and its implications for monetary policy'. IMF World Economic Outlook (April 2008) pp. 103-130

[28] Mishkin, Frederic S. (2007) 'Housing and the monetary transmission mechanism'. NBER Working Papers 13518, National Bureau of Economic Research, Inc, October

[29] Paustian, Matthias (2007) 'Assessing sign restrictions'. The B.E. Journal of Macroeconomics (Topics) 
[31] Pesaran, M. Hashem, and Ron Smith (1995) 'Estimating long-run relationships from dynamic heterogeneous panels'. Journal of Econometrics 68(1), 79-113

[31] Pesaran, M. Hashem, Schuermann, Til and Vanessa Smith (2009) 'Forecasting economic and financial variables using global VARs'. International Journal of Forecasting 25(4), 642-675

[32] Primiceri, Giorgio E. (2005), 'Time Varying Structural Vector Autoregressions and Monetary Policy'. Review of Economic Studies, 72(3), 821-852

[33] Rajan, Raghuram G. (2005) 'Has financial development made the world riskier?' NBER Working Papers 11728, National Bureau of Economic Research, Inc, November

[34] Reinhart, Carmen M., and Vincent R. Reinhart (2008) 'Capital flow bonanzas: An encompassing view of the past and present'. NBER Working Papers 14321, National Bureau of Economic Research, Inc, September

[35] Rubio-Ramirez, Juan F., Daniel F. Waggoner, and Tao Zha (2010) 'Structural vector autoregressions: Theory of identification and algorithms for inference'. Review of Economic Studies $77(2), 665-696$

[36] Sá, Filipa, and Francesca Viani (2010) 'Shifts in portfolio preferences of foreign investors: an application to sovereign wealth funds'. Cambridge Working Papers in Economics No. 1029.

[37] Sá, Filipa, and Tomasz Wieladek (2010) 'Monetary policy, capital inflows and the US housing bubble'. Bank of England Working Paper No. 405.

[38] Scholl, Almuth, and Harald Uhlig (2008) 'New evidence on the puzzles: Results from agnostic identification on monetary policy and exchange rates'. Journal of International Economics $76(1), 1-13$

[39] Sims, Christopher A. (1988) 'Bayesian skepticism on unit root econometrics'. Journal of Economic Dynamics and Control 12(2-3), 463-474

[40] Taylor, John B. (2009) 'The financial crisis and the policy responses: An empirical analysis of what went wrong'. NBER Working Papers 14631, National Bureau of Economic Research, Inc, January

[41] Towbin, Pascal, and Sebastian Weber (2010) 'Limits of floats - the role of foreign currency debt and import structure'. HEID Working Papers 01-2010, Graduate Institute of International and Development Studies, Geneva

[42] Uhlig, Harald (2005) 'What are the effects of monetary policy on output? Results from an agnostic identification procedure'. Journal of Monetary Economics 52(2), 381-419

[43] Warnock, Francis E., and Veronica Warnock (2009) 'International capital flows and U.S. interest rates'. Journal of International Money and Finance 28(6), 903 - 919 
[44] Zettelmeyer, Jeromin (2004) 'The impact of monetary policy on the exchange rate: evidence from three small open economies'. Journal of Monetary Economics 51(3), 635-652 
Figure 1. House prices and the current account

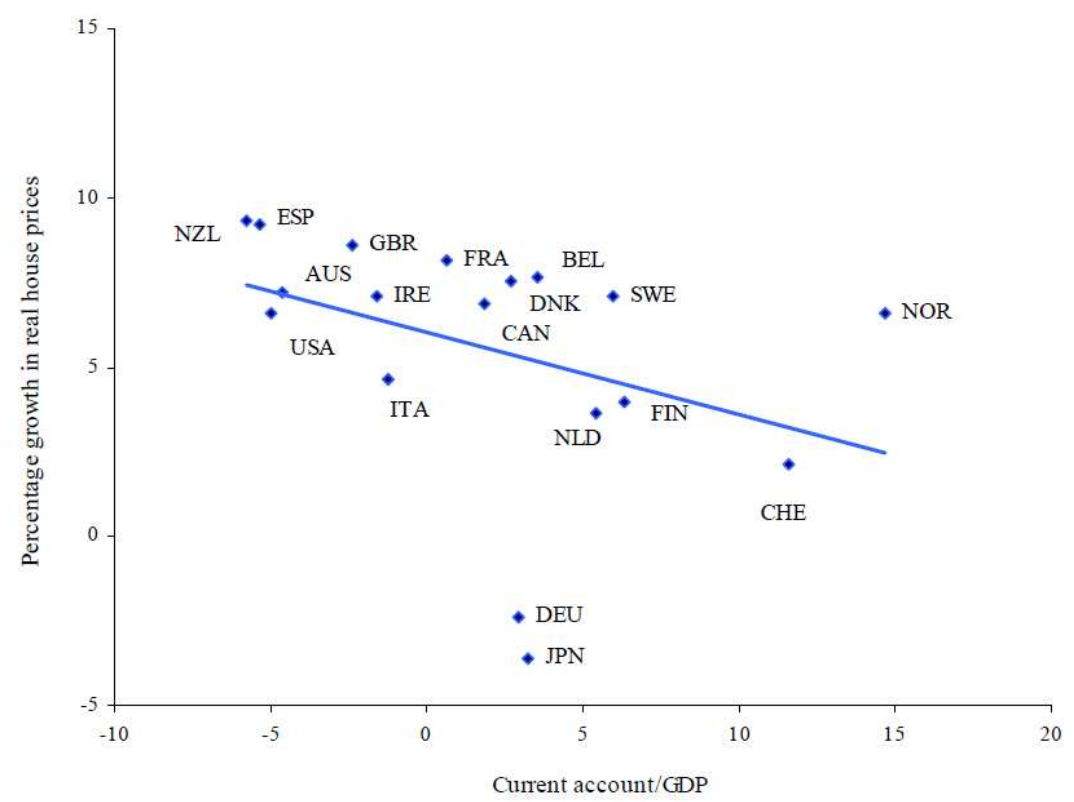

Notes: Data are averages over the period 1999 Q1 to 2006 Q4. Current account/GDP is from the OECD Economic Outlook. Real house price index is from the BIS Property Price Statistics.

Figure 2. Index of mortgage market development - IMF (2008)

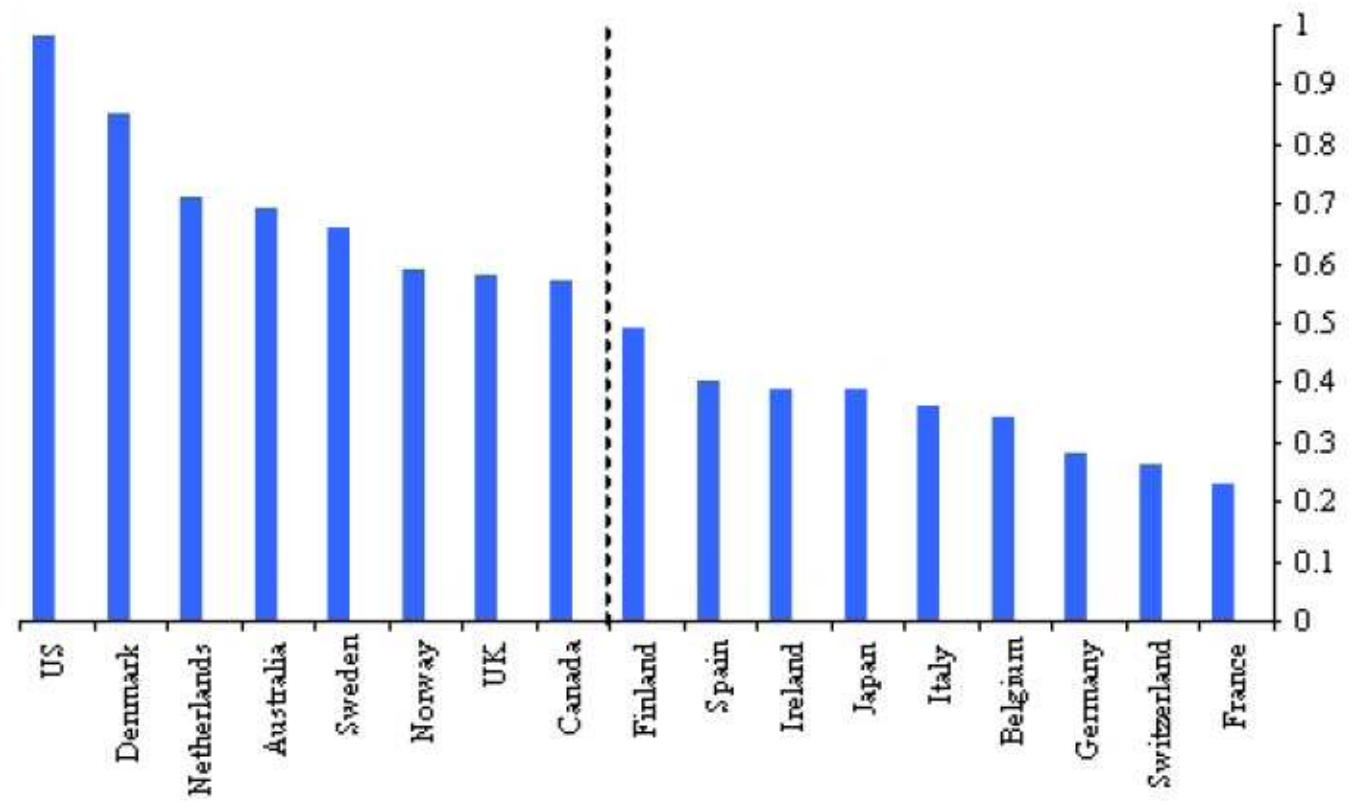


Figure 3. Impulse responses to capital inflows shock
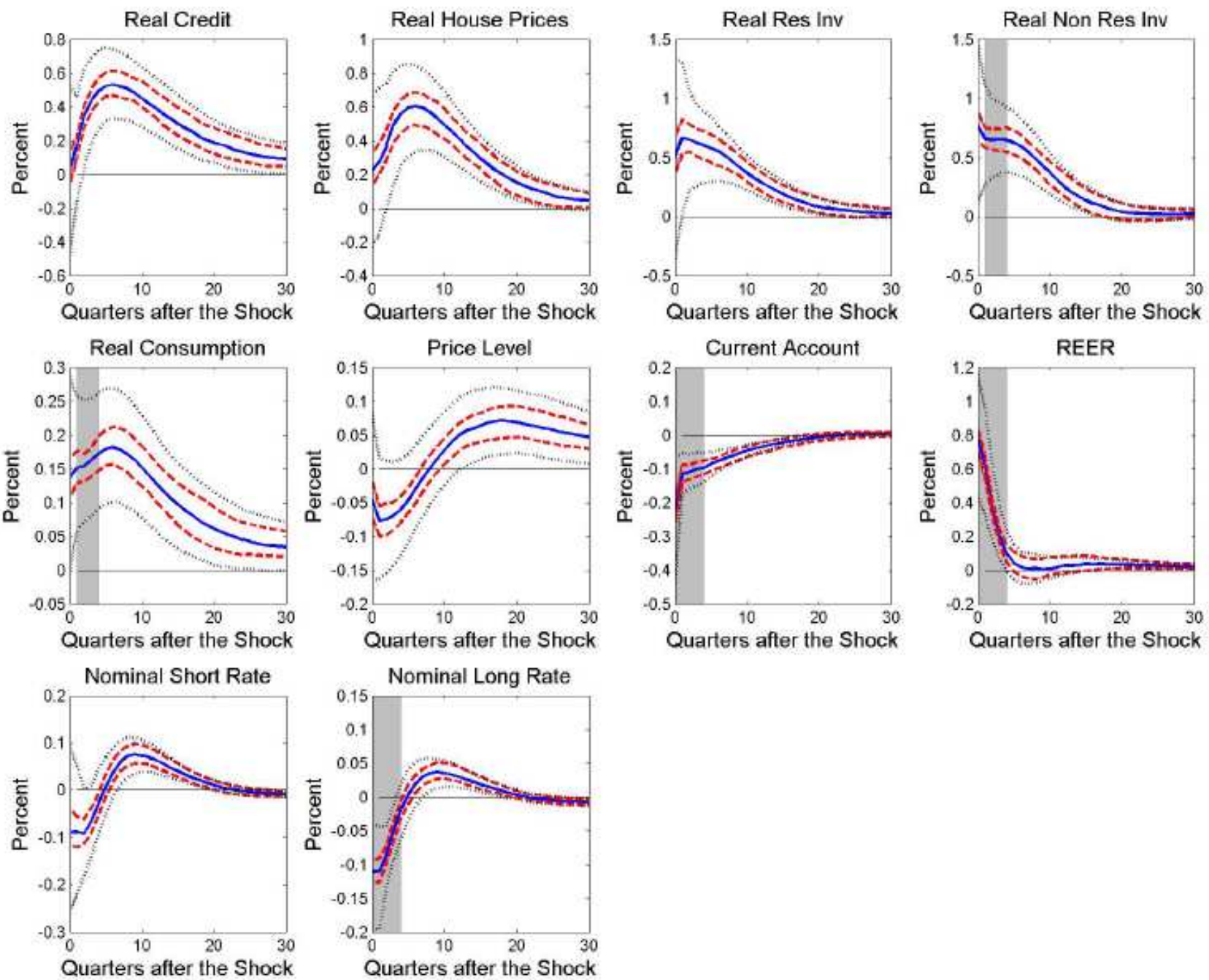

Notes: The size of the shocks is normalized to one standard deviation. The median is represented by the solid blue line. The 16th and 84th percentiles are represented by dashed red lines when accounting for parameter uncertainty and by dotted black lines when accounting for identification uncertainty. The grey shaded area indicates the variables and the horizon for which sign restrictions are imposed. 
Figure 4. Impulse responses to monetary policy shock
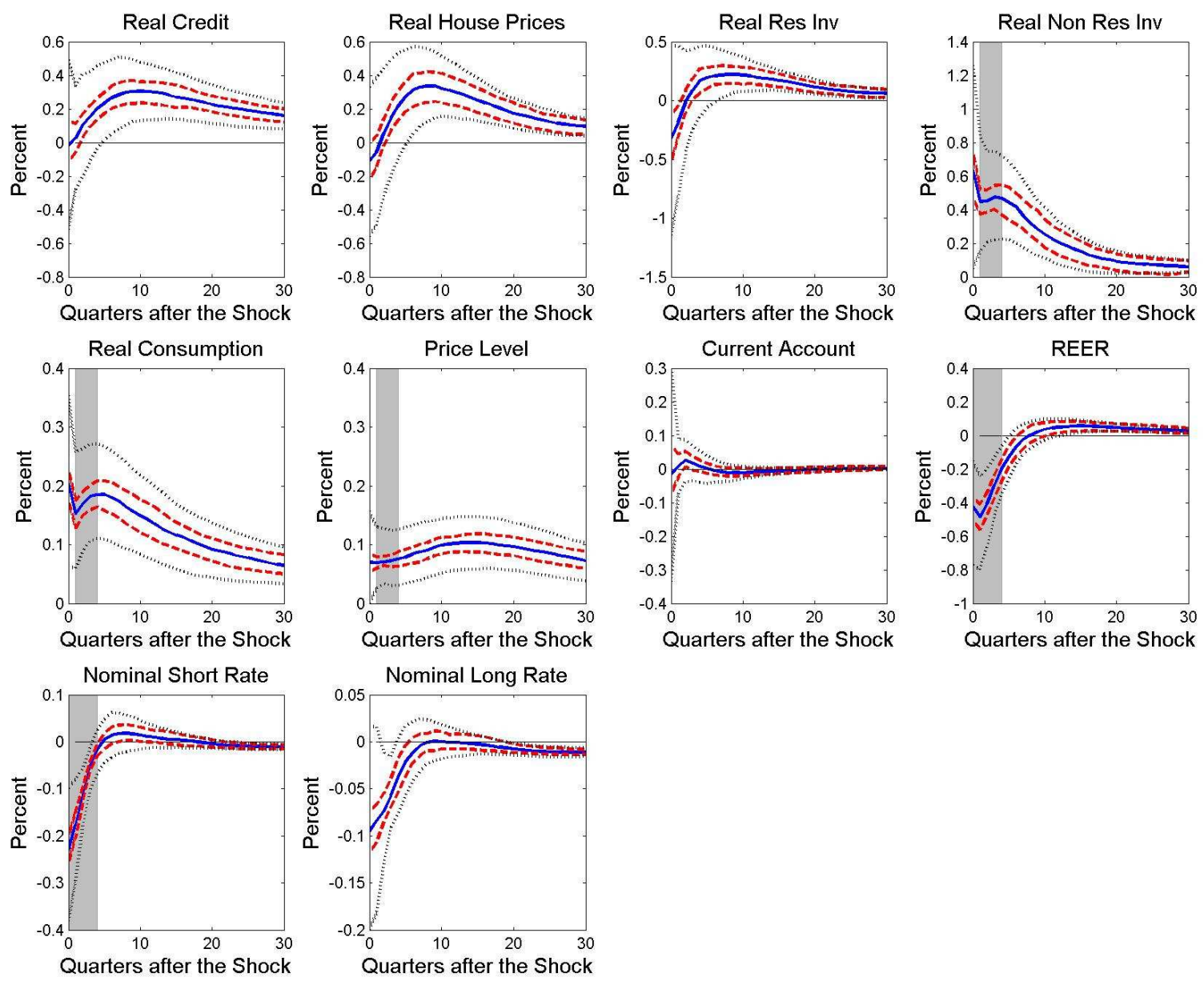

Notes: The size of the shocks is normalized to one standard deviation. The median is represented by the solid blue line. The 16th and 84th percentiles are represented by dashed red lines when accounting for parameter uncertainty and by dotted black lines when accounting for identification uncertainty. The grey shaded area indicates the variables and the horizon for which sign restrictions are imposed. 
Figure 5. The role of mortgage market development: response of housing variables to capital inflows shock
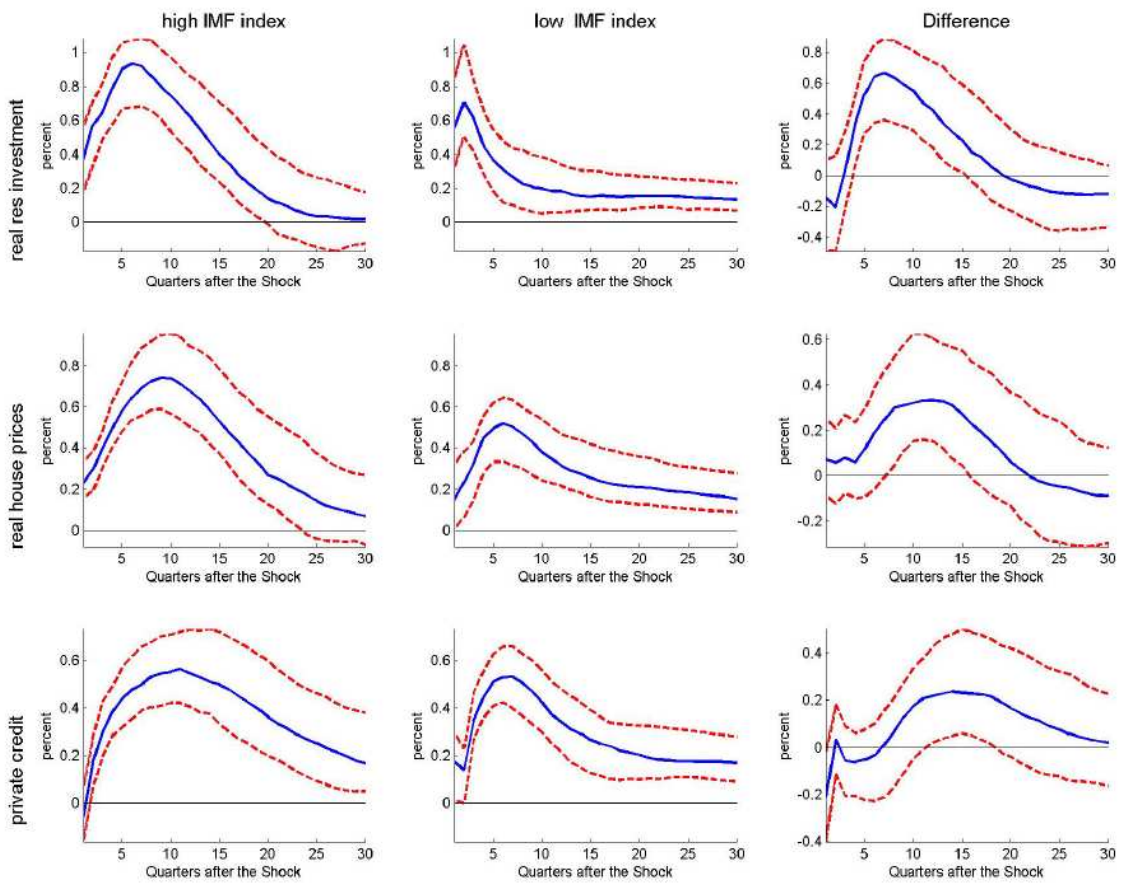

Notes: The size of the shocks is normalized to one standard deviation. The median is represented by the solid blue line. The 16th and 84th percentiles that account for parameter uncertainty are represented by dashed red lines.

Figure 6. The role of mortgage market development: response of housing variables to monetary policy shock
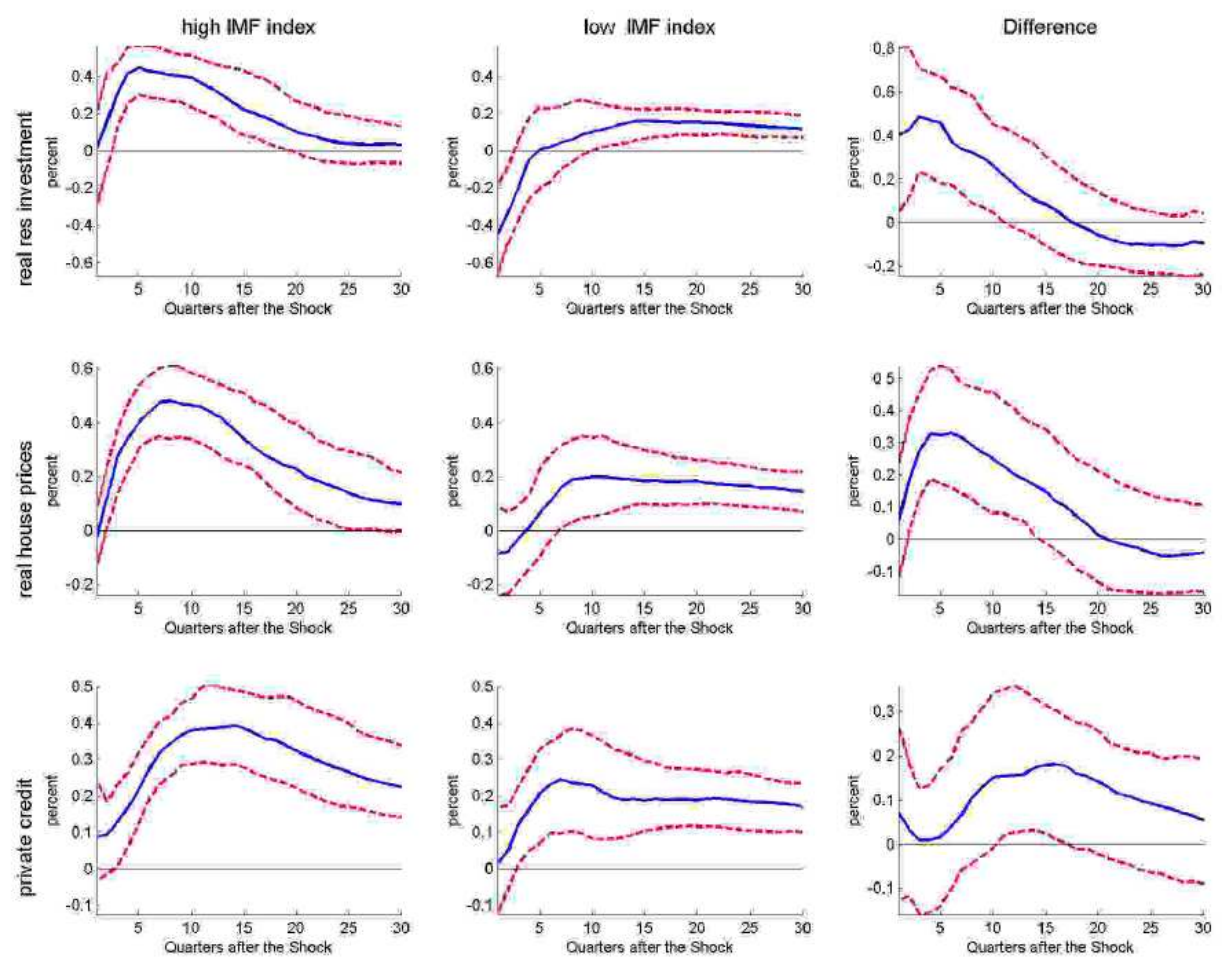

Notes: The size of the shocks is normalized to one standard deviation. The median is represented by the solid blue line. The 16th and 84th percentiles that account for parameter uncertainty are represented by dashed red lines. 
Figure 7. The role of mortgage market development: response of non-housing variables to capital inflows shock
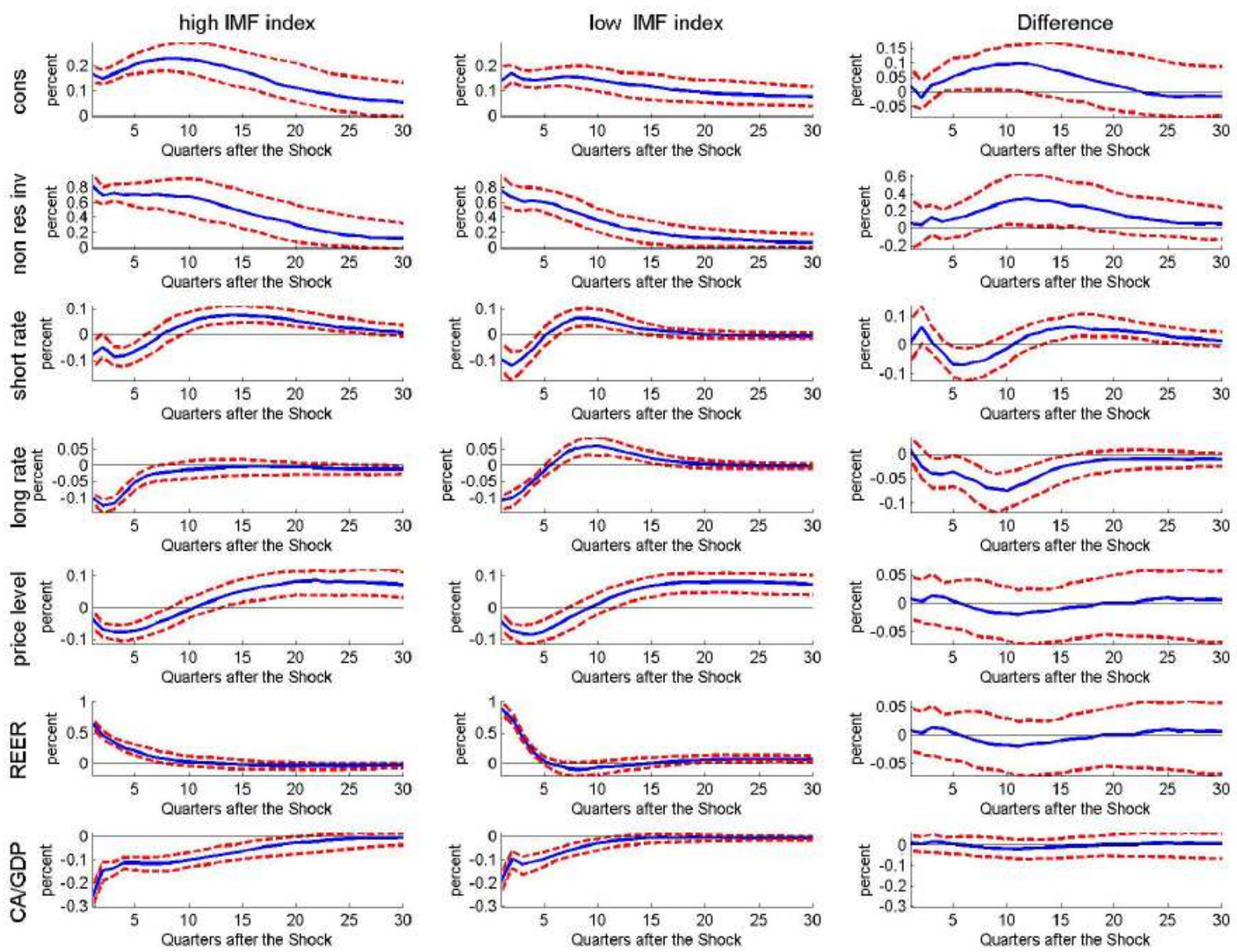

Notes: The size of the shocks is normalized to one standard deviation. The median is represented by the solid blue line. The 16 th and 84th percentiles that account for parameter uncertainty are represented by dashed red lines. 
Figure 8 . The role of mortgage market development: response of non-housing variables to monetary policy shock
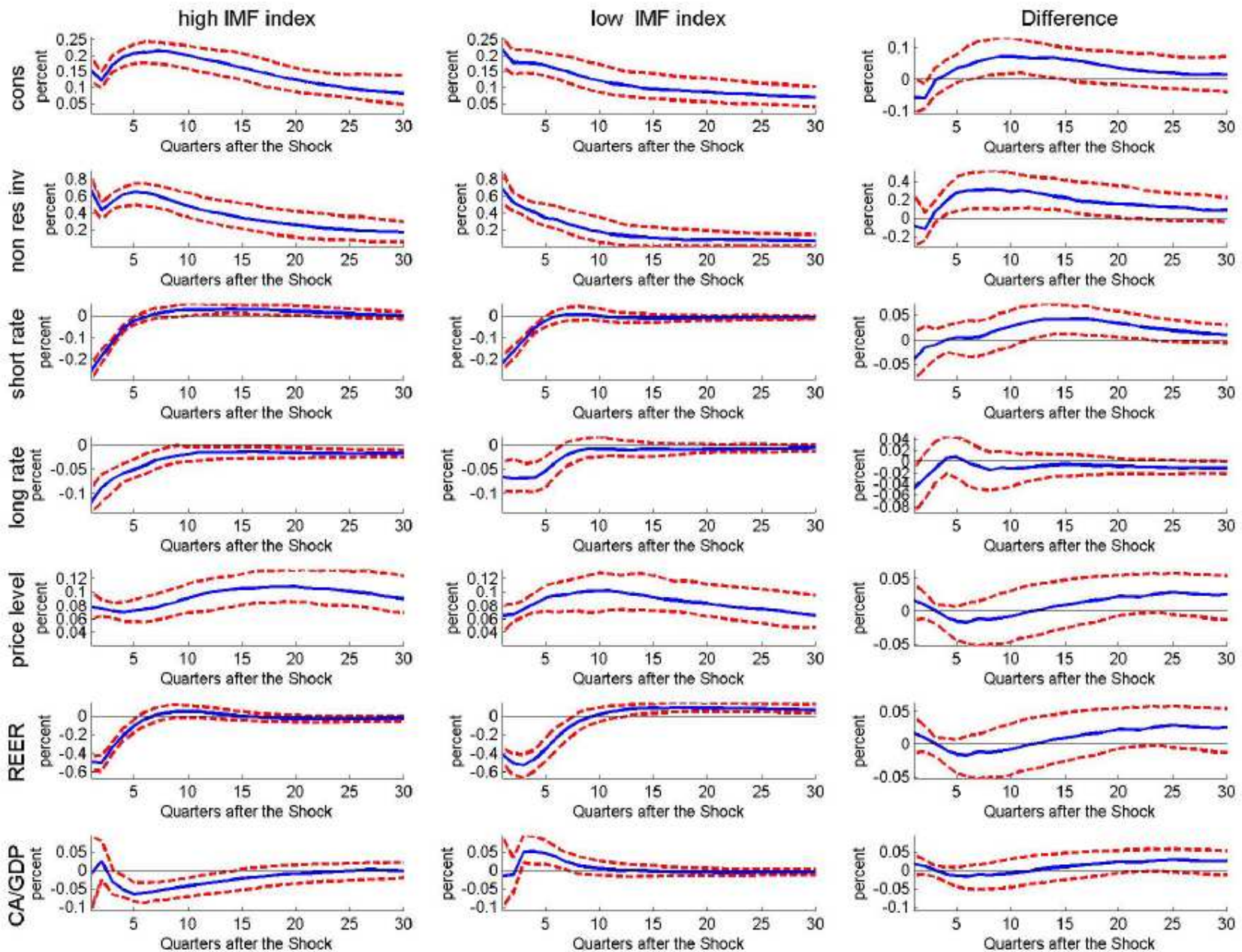

Notes: The size of the shocks is normalized to one standard deviation. The median is represented by the solid blue line. The 16th and 84th percentiles that account for parameter uncertainty are represented by dashed red lines. 
Figure 9. The role of securitization: response of housing variables to capital inflows shock
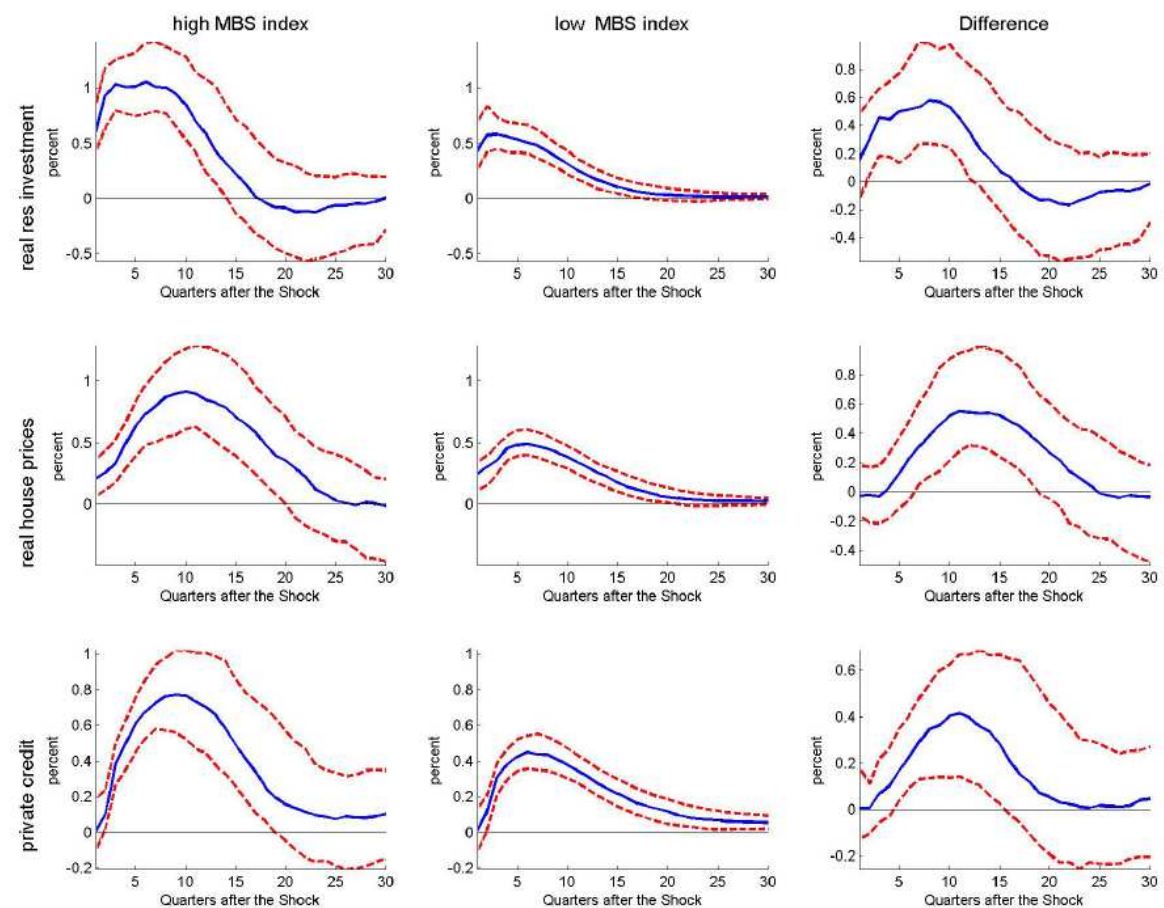

Notes: The size of the shocks is normalized to one standard deviation. The median is represented by the solid blue line. The 16 th and 84th percentiles that account for parameter uncertainty are represented by dashed red lines.

Figure 10. The role of securitization: response of housing variables to monetary policy shock
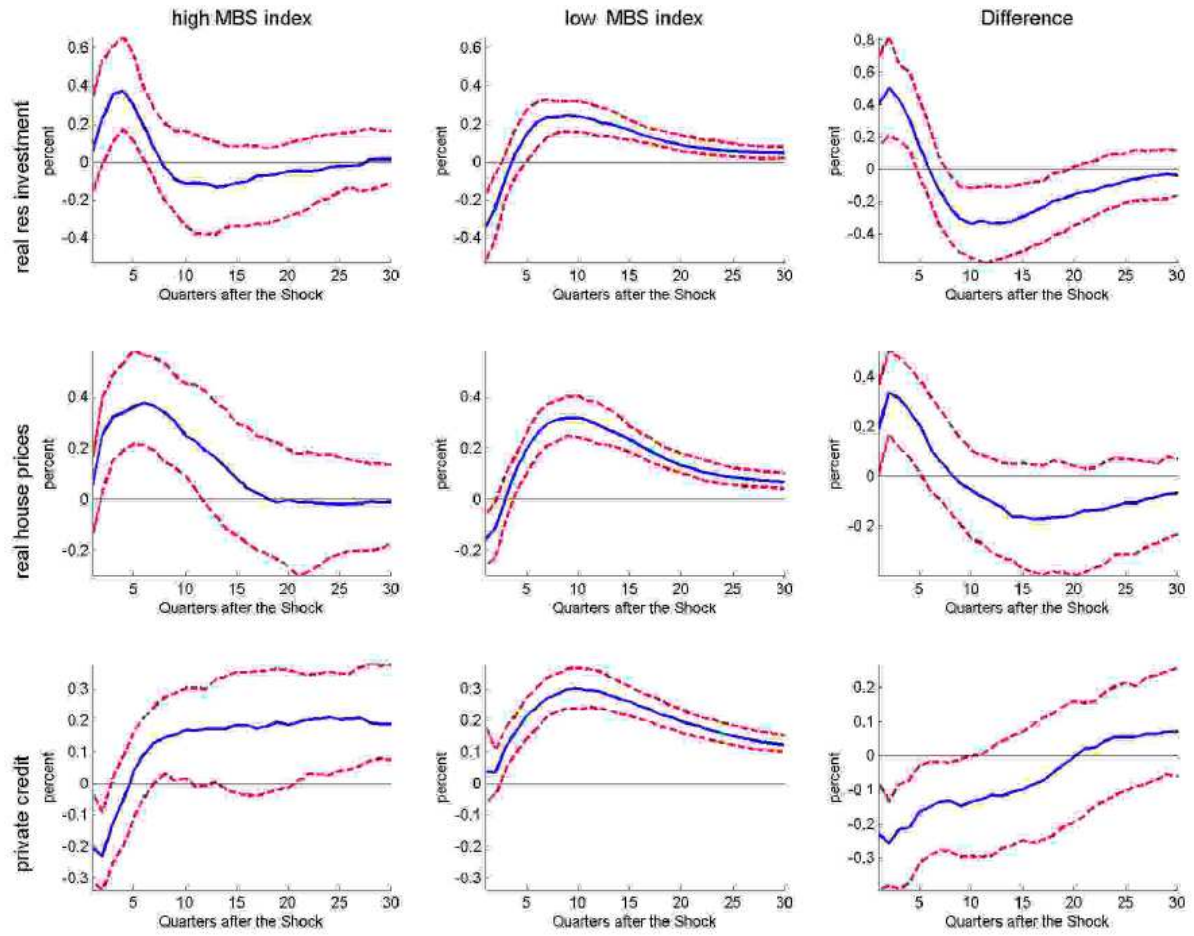

Notes: The size of the shocks is normalized to one standard deviation. The median is represented by the solid blue line. The 16th and 84th percentiles that account for parameter uncertainty are represented by dashed red lines. 
Figure 11. The role of securitization: response of non-housing variables to capital inflows shock
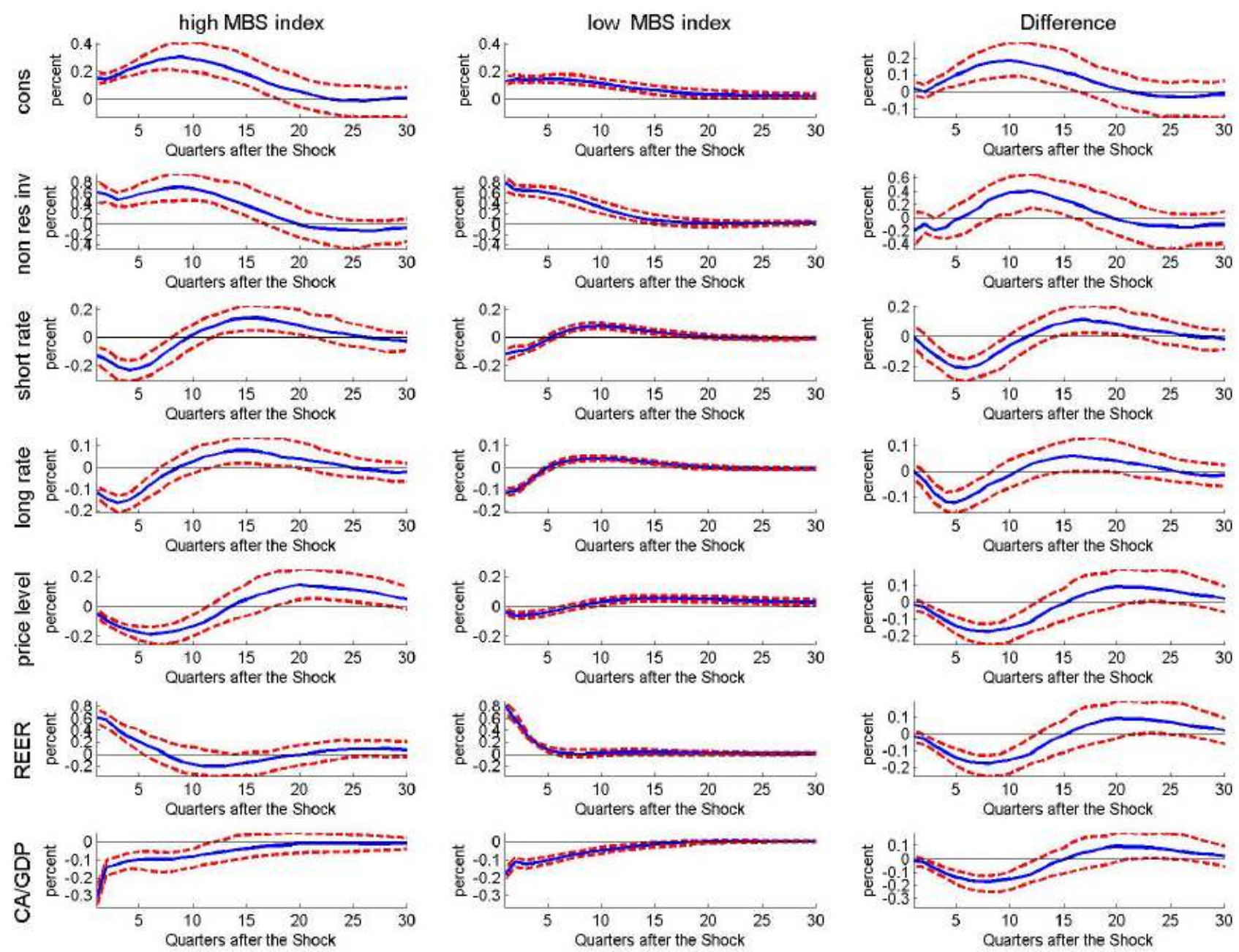

Notes: The size of the shocks is normalized to one standard deviation. The median is represented by the solid blue line. The 16 th and 84th percentiles that account for parameter uncertainty are represented by dashed red lines. 
Figure 12. The role of securitization: response of non-housing variables to monetary policy shock

high MBS index
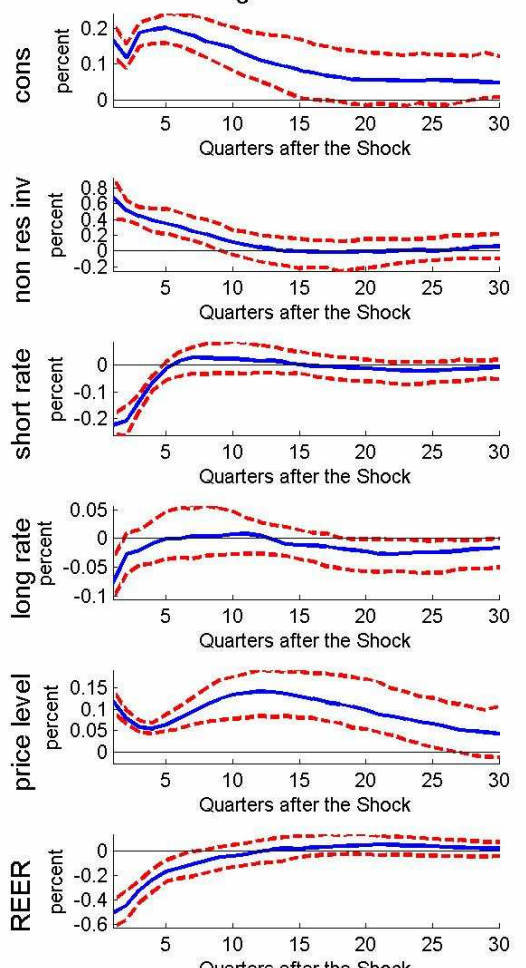

Quarters after the Shock

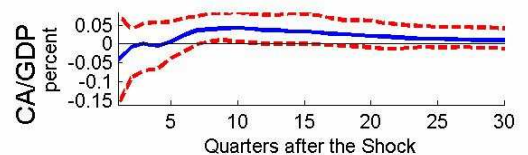

low MBS index
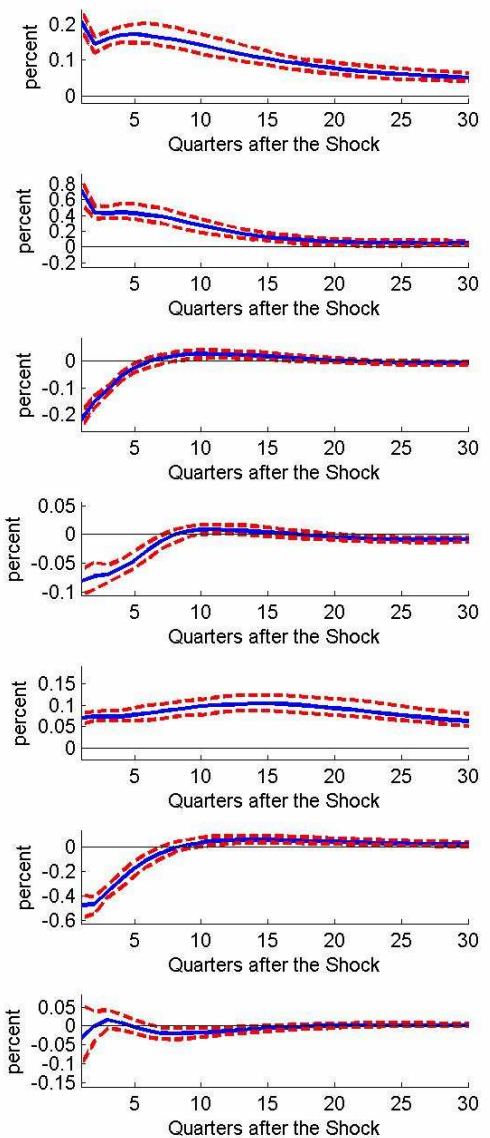

Difference
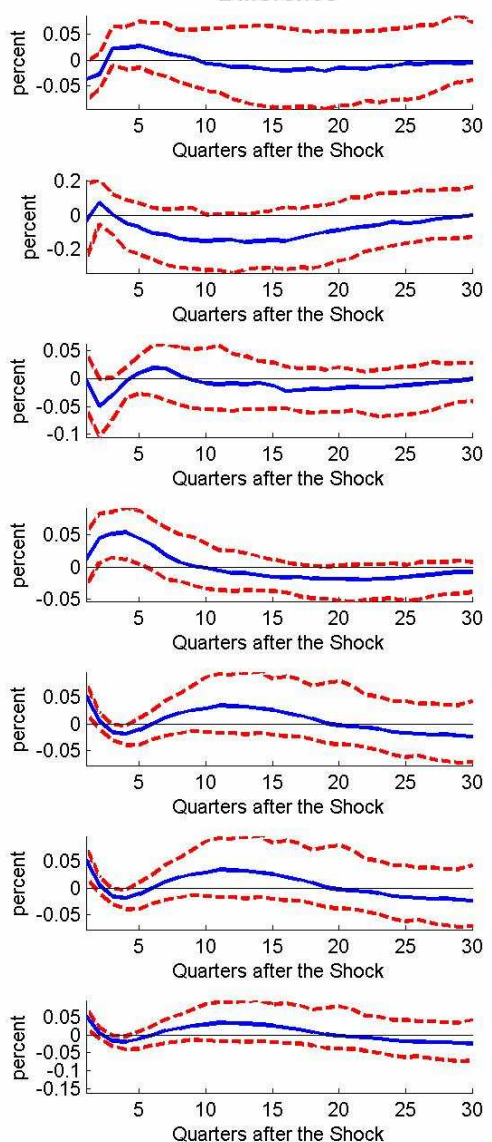

Notes: The size of the shocks is normalized to one standard deviation. The median is represented by the solid blue line. The 16th and 84th percentiles that account for parameter uncertainty are represented by dashed red lines. 
Table 1. Data sources

\begin{tabular}{|c|c|c|}
\hline & Database & Remarks \\
\hline Current Account to GDP ratio & OECD & $\begin{array}{l}\text { sa }^{a} \text {, Denmark: IFS, seasonally } \\
\text { adjusted in Eviews using addi- } \\
\text { tive X12 filter }\end{array}$ \\
\hline Consumer Price Index & OECD & sa \\
\hline Real Consumption & OECD & sa \\
\hline Long term nominal interest rate & OECD & Germany: IFS \\
\hline Short term nominal interest rate & OECD & Ireland, Sweden: IFS \\
\hline Real Private Credit & IFS & $\begin{array}{l}\text { Line } 22 \mathrm{~d} \text {, deflated with GDP } \\
\text { deflator, adjusted for level } \\
\text { shifts }^{b}\end{array}$ \\
\hline Real Residential Investment & OECD & $\begin{array}{l}\text { Gross fixed capital forma- } \\
\text { tion, housing, for Switzerland: } \\
\text { Gross fixed capital formation, } \\
\text { construction, for Italy: na- } \\
\text { tional sources }\end{array}$ \\
\hline Real Non Residential Investment & OECD & $\begin{array}{l}\text { Total investment minus resi- } \\
\text { dential investment, for Italy: } \\
\text { national sources }\end{array}$ \\
\hline Real House Prices & BIS & \\
\hline Reel Effective Exchange Rate & BIS & \\
\hline Commodity Price Index & BIS & \\
\hline Gross Domestic Product Deflator & $\mathrm{OECD}$ & sa DEU: IFS \\
\hline World GDP & Pesaran et al. (2009) & $\begin{array}{l}\text { Trade weights based on IMF } \\
\text { DOTS }\end{array}$ \\
\hline World Prices & Pesaran et al. (2009) & $\begin{array}{l}\text { Trade weights based on IMF } \\
\text { DOTS }\end{array}$ \\
\hline
\end{tabular}

Notes: ${ }^{a}$ seasonally adjusted; ${ }^{b}$ As in Goodhart and Hoffman (2008) we adjust for level shifts that occur because of redefinitions or reclassifications by replacing the growth rate in the quarter where the shift occurs with median growth of the two quarters before and after the shift. Level shifts occur for the following countries at the following dates: AUS 1984Q3, 1984Q4, 1988Q4; BEL 1992Q4; CAN 1981Q1, 2001Q4; CHE 1974Q4, 1982Q3; DEU 1990Q2, 1999Q1; DNK 1991Q1, 2000Q3; FRA 1978Q1; ITA 1991Q1, 1999Q1; IRE 1970Q2, 1982Q4, 1995Q1; JPN 1997Q4, 2001Q4; NLD 1988Q4; NZL 1988Q3. 
Table 2. Mortgage market development: sample splits

\begin{tabular}{|c|c|c|}
\hline & High Develompent Groups & Low Development Group \\
\hline Mortgage Debt to GDP ratio & $\begin{array}{l}\text { Australia, Denmark, Ireland, } \\
\text { Netherlands, New Zealand, } \\
\text { Norway, Switzerland, United } \\
\text { Kingdom, United States }\end{array}$ & $\begin{array}{l}\text { Belgium, Canada, Finland, } \\
\text { France, Germany, Italy, } \\
\text { Japan, Spain, Sweden, }\end{array}$ \\
\hline Mortgage Equity Withdrawal & $\begin{array}{l}\text { Australia, Denmark, Finland, } \\
\text { Netherlands, Norway, New } \\
\text { Zealand, Sweden, United } \\
\text { Kingdom, United States }\end{array}$ & $\begin{array}{l}\text { Belgium, France, Germany, } \\
\text { Spain, Switzerland, Ireland, } \\
\text { Japan, Canada, Italy }\end{array}$ \\
\hline Typical Loan to Value Ratio & $\begin{array}{l}\text { Australia, Belgium, Denmark, } \\
\text { Netherlands, Sweden, United } \\
\text { Kingdom, United States }\end{array}$ & $\begin{array}{l}\text { Canada, Finland, France, } \\
\text { Germany, Ireland, Italy, } \\
\text { Japan, New Zealand, Norway, } \\
\text { Spain, Switzerland }\end{array}$ \\
\hline
\end{tabular}

Table 3. Sign restrictions

Capital Inflows Shock Monetary Policy Shock

\begin{tabular}{lll}
\hline Short-term nominal interest rate & & - \\
Long-term real interest rate & - & - \\
Real Exchange Rate & + & \\
Current Account & - & + \\
Consumer Price Index & & + \\
Consumption & + & + \\
Non residential investment & + & - \\
\hline
\end{tabular}




\begin{tabular}{lcccccc}
\hline & \multicolumn{3}{c}{ Monetary Policy Shock } & \multicolumn{3}{c}{ Capital Inflows Shock } \\
& 1 year & 3 years & 10 years & 1 year & 3 years & 10 years \\
Baseline & & & & & & \\
real credit & 3.92 & 5.67 & 8.35 & 6.87 & 13.67 & 13.19 \\
real house prices & 3.42 & 5.57 & 6.95 & 6.02 & 12.21 & 12.78 \\
real res investment & 3.51 & 4.55 & 5.51 & 7.58 & 11.68 & 11.79 \\
IMF Index high & & & & & & \\
real credit & 3.65 & 6.55 & 9.08 & 5.83 & 13.33 & 14.33 \\
real house prices & 4.53 & 7.13 & 7.83 & 6.31 & 14.12 & 15.23 \\
real res investment & 4.70 & 5.75 & 6.11 & 7.05 & 13.99 & 14.17 \\
$\begin{array}{l}\text { IMF Index low } \\
\text { real credit }\end{array}$ & 3.88 & 4.51 & 6.16 & 6.51 & 12.00 & 11.74 \\
real house prices & 3.46 & 4.32 & 5.82 & 5.28 & 9.56 & 10.49 \\
real res investment & 3.80 & 4.65 & 5.88 & 6.26 & 7.12 & 8.23 \\
$\begin{array}{l}M B S \text { Index high } \\
\text { real credit }\end{array}$ & 4.33 & 3.93 & 5.70 & 7.60 & 19.25 & 17.25 \\
real house prices & 4.92 & 4.22 & 4.36 & 5.91 & 16.60 & 17.33 \\
real res investment & 4.31 & 3.78 & 4.36 & 11.96 & 17.73 & 16.91 \\
$\begin{array}{l}\text { MBS Index low } \\
\text { real credit }\end{array}$ & 3.85 & 6.25 & 8.59 & 6.24 & 11.03 & 10.88 \\
real house prices & 3.23 & 5.96 & 7.56 & 5.40 & 9.86 & 9.97 \\
real res investment & 3.39 & 4.52 & 5.38 & 6.05 & 9.26 & 9.32 \\
\hline
\end{tabular}


Table 5. Mortgage market development: results for different sample periods

\begin{tabular}{ccccccc}
\hline \multicolumn{2}{c}{ High } & \multicolumn{2}{c}{ Low } & \multicolumn{2}{c}{ Difference } \\
\cline { 2 - 7 } & $4 \mathrm{q}$ & $12 \mathrm{q}$ & $4 \mathrm{q}$ & $12 \mathrm{q}$ & $4 \mathrm{q}$ & $12 \mathrm{q}$ \\
\hline
\end{tabular}

IMF Index

Monetary Policy Shock

$\begin{array}{ccccccc}\text { pr cred. } & 0.17 & 0.38 & 0.16 & 0.19 & 0.01 & 0.16 \\ & (0.06,0.26) & (0.29,0.50) & (0.05,0.28) & (0.08,0.33) & (-0.15,0.14) & (0.03,0.36) \\ \text { house pr. } & 0.34 & 0.44 & 0.01 & 0.19 & 0.33 & 0.20 \\ & (0.22,0.47) & (0.30,0.55) & (-0.14,0.13) & (0.07,0.33) & (0.19,0.53) & (0.06,0.41) \\ \text { res. inv. } & 0.42 & 0.33 & -0.05 & 0.13 & 0.47 & 0.18 \\ & (0.25,0.56) & (0.19,0.47) & (-0.26,0.18) & (0.03,0.23) & (0.21,0.69) & (-0.02,0.41)\end{array}$

Capital Inflows Shock

$\begin{array}{ccccccc}\text { pr cred. } & 0.38 & 0.54 & 0.45 & 0.34 & -0.06 & 0.22 \\ & (0.28,0.49) & (0.41,0.73) & (0.36,0.56) & (0.21,0.48) & (-0.21,0.06) & (0.02,0.43) \\ \text { house pr. } & 0.50 & 0.67 & 0.45 & 0.31 & 0.06 & 0.33 \\ & (0.40,0.62) & (0.50,0.89) & (0.28,0.56) & (0.21,0.46) & (-0.10,0.23) & (0.15,0.60) \\ \text { res. inv. } & 0.79 & 0.62 & 0.44 & 0.18 & 0.33 & 0.42 \\ & (0.58,0.97) & (0.41,0.86) & (0.28,0.65) & (0.06,0.34) & (0.07,0.51) & (0.18,0.74)\end{array}$

IMF Index ( since 1990)

Monetary Policy Shock

\begin{tabular}{lcccccc} 
pr cred. & 0.07 & 0.20 & 0.16 & 0.20 & -0.10 & 0.01 \\
& $(-0.07,0.21)$ & $(0.13,0.30)$ & $(0.06,0.27)$ & $(0.10,0.30)$ & $(-0.29,0.09)$ & $(-0.14,0.15)$ \\
house pr. & 0.36 & 0.12 & 0.02 & 0.08 & 0.32 & 0.03 \\
& $(0.22,0.50)$ & $(0.01,0.28)$ & $(-0.09,0.17)$ & $(-0.00,0.16)$ & $(0.16,0.52)$ & $(-0.10,0.22)$ \\
res. inv. & 0.50 & 0.00 & 0.13 & 0.10 & 0.38 & -0.13 \\
& $(0.29,0.72)$ & $(-0.15,0.15)$ & $(-0.04,0.30)$ & $(-0.01,0.22)$ & $(0.11,0.67)$ & $(-0.29,0.09)$ \\
Capital Inflows Shock & & & & & \\
pr cred. & 0.30 & 0.23 & 0.27 & 0.22 & 0.01 & 0.01 \\
& $(0.20,0.41)$ & $(0.11,0.36)$ & $(0.17,0.36)$ & $(0.13,0.35)$ & $(-0.11,0.22)$ & $(-0.16,0.19)$ \\
house pr. & 0.46 & 0.45 & 0.33 & 0.17 & 0.15 & 0.29 \\
& $(0.30,0.63)$ & $(0.27,0.80)$ & $(0.19,0.43)$ & $(0.09,0.27)$ & $(-0.06,0.35)$ & $(0.04,0.60)$ \\
res. inv. & 0.48 & 0.27 & 0.40 & 0.15 & 0.10 & 0.10 \\
& $(0.25,0.69)$ & $(0.08,0.55)$ & $(0.16,0.64)$ & $(0.06,0.33)$ & $(-0.22,0.31)$ & $(-0.13,0.41)$ \\
\hline
\end{tabular}


Table 6. Mortgage market development: results for different sample-splitting criteria

\begin{tabular}{|c|c|c|c|c|c|c|}
\hline & \multicolumn{2}{|c|}{$\mathrm{High}$} & \multicolumn{2}{|c|}{ Low } & \multicolumn{2}{|c|}{ Difference } \\
\hline & $4 \mathrm{q}$ & $12 \mathrm{q}$ & $4 \mathrm{q}$ & $12 \mathrm{q}$ & $4 \mathrm{q}$ & $12 \mathrm{q}$ \\
\hline \multicolumn{7}{|c|}{ Mortgage Debt } \\
\hline \multicolumn{7}{|c|}{ Monetary Policy Shock } \\
\hline \multirow[t]{2}{*}{ prcred. } & 0.18 & 0.36 & 0.11 & 0.29 & 0.04 & 0.07 \\
\hline & $(0.06,0.27)$ & $(0.25,0.43)$ & $(0.03,0.21)$ & $(0.15,0.41)$ & $(-0.12,0.20)$ & $(-0.09,0.23)$ \\
\hline \multirow[t]{2}{*}{ house pr. } & 0.30 & 0.45 & -0.00 & 0.25 & 0.29 & 0.18 \\
\hline & $(0.18,0.45)$ & $(0.31,0.58)$ & $(-0.11,0.15)$ & $(0.15,0.38)$ & $(0.13,0.47)$ & $(0.01,0.38)$ \\
\hline \multirow[t]{2}{*}{ res. in v. } & 0.31 & 0.28 & -0.09 & 0.17 & 0.40 & 0.10 \\
\hline & $(0.19,0.48)$ & $(0.18,0.48)$ & $(-0.24,0.07)$ & $(0.05,0.30)$ & $(0.18,0.66)$ & $(-0.05,0.36)$ \\
\hline \multicolumn{7}{|c|}{ Capital In flows Shock } \\
\hline \multirow[t]{2}{*}{ prered. } & 0.50 & 0.58 & 0.44 & 0.36 & 0.07 & 0.23 \\
\hline & $(0.43,0.58)$ & $(0.44,0.75)$ & $(0.34,0.54)$ & $(0.21,0.48)$ & $(-0.04,0.20)$ & $(0.02,0.46)$ \\
\hline \multirow[t]{2}{*}{ house pr. } & 0.58 & 0.78 & 0.50 & 0.26 & 0.07 & 0.52 \\
\hline & $(0.44,0.68)$ & $(0.63,1.00)$ & $(0.37,0.64)$ & $(0.15,0.42)$ & $(-0.12,0.26)$ & $(0.32,0.78)$ \\
\hline \multirow[t]{2}{*}{ res. in v. } & 0.78 & 0.60 & 0.57 & 0.22 & 0.22 & 0.38 \\
\hline & $(0.65,0.90)$ & $(0.43,0.90)$ & $(0.35,0.76)$ & $(0.09,0.39)$ & $(0.02,0.40)$ & $(0.17,0.66)$ \\
\hline \multicolumn{7}{|l|}{$M E W$} \\
\hline \multicolumn{7}{|c|}{ Monetary Policy Shock } \\
\hline \multirow[t]{2}{*}{ prcred. } & 0.14 & 0.35 & 0.16 & 0.21 & 0.00 & 0.13 \\
\hline & $(0.09,0.24)$ & $(0.24,0.43)$ & $(0.06,0.26)$ & $(0.07,0.32)$ & $(-0.13,0.14)$ & $(0.00,0.30)$ \\
\hline \multirow[t]{2}{*}{ house pr. } & 0.37 & 0.47 & 0.01 & 0.16 & 0.37 & 0.30 \\
\hline & $(0.25,0.48)$ & $(0.33,0.60)$ & $(-0.14,0.12)$ & $(0.02,0.30)$ & $(0.22,0.53)$ & $(0.13,0.46)$ \\
\hline \multirow[t]{2}{*}{ res. in v. } & 0.32 & 0.34 & -0.08 & 0.10 & 0.39 & 0.26 \\
\hline & $(0.19,0.42)$ & $(0.20,0.47)$ & $(-0.28,0.14)$ & $(-0.02,0.21)$ & $(0.12,0.62)$ & $(0.09,0.42)$ \\
\hline \multicolumn{7}{|c|}{ Capital Inflows Shock } \\
\hline \multirow[t]{2}{*}{ prcred. } & 0.43 & 0.47 & 0.46 & 0.38 & -0.03 & 0.10 \\
\hline & $(0.36,0.52)$ & $(0.37,0.60)$ & $(0.37,0.57)$ & $(0.26,0.54)$ & $(-0.16,0.09)$ & $(-0.08,0.27)$ \\
\hline \multirow[t]{2}{*}{ house pr. } & 0.56 & 0.69 & 0.49 & 0.39 & 0.06 & 0.30 \\
\hline & $(0.47,0.66)$ & $(0.55,0.92)$ & $(0.38,0.62)$ & $(0.24,0.55)$ & $(-0.11,0.21)$ & $(0.11,0.55)$ \\
\hline \multirow[t]{2}{*}{ res. in v. } & 0.66 & 0.58 & 0.74 & 0.24 & -0.08 & 0.34 \\
\hline & $(0.51,0.79)$ & $(0.44,0.75)$ & $(0.52,0.92)$ & $(0.09,0.41)$ & $(-0.33,0.17)$ & $(0.14,0.57)$ \\
\hline \multicolumn{7}{|c|}{ Loan To Value } \\
\hline Monetary & Policy Shoc & & & & & \\
\hline prcred. & 0.12 & 0.35 & 0.17 & 0.28 & -0.05 & 0.06 \\
\hline & $(0.02,0.24)$ & $(0.23,0.47)$ & $(0.10,0.24)$ & $(0.20,0.35)$ & $(-0.19,0.10)$ & $(-0.04,0.20)$ \\
\hline house pr. & 0.21 & 0.34 & 0.09 & 0.28 & 0.11 & 0.07 \\
\hline & $(0.09,0.33)$ & $(0.20,0.49)$ & $(-0.04,0.20)$ & $(0.19,0.41)$ & $(-0.05,0.27)$ & $(-0.13,0.25)$ \\
\hline res. in v. & 0.25 & 0.22 & 0.12 & 0.22 & 0.12 & -0.01 \\
\hline & $(0.06,0.43)$ & $(0.08,0.36)$ & $(-0.05,0.26)$ & $(0.15,0.30)$ & $(-0.13,0.37)$ & $(-0.16,0.16)$ \\
\hline Capital In $f$ & low s Shock & & & & & \\
\hline prcred. & 0.42 & 0.51 & 0.50 & 0.36 & -0.06 & 0.16 \\
\hline & $(0.34,0.53)$ & $(0.38,0.71)$ & $(0.42,0.59)$ & $(0.26,0.46)$ & $(-0.20,0.04)$ & $(-0.03,0.39)$ \\
\hline house pr. & 0.38 & 0.59 & 0.51 & 0.40 & -0.13 & 0.22 \\
\hline & $(0.28,0.48)$ & $(0.47,0.84)$ & $(0.34,0.63)$ & $(0.26,0.51)$ & $(-0.33,0.08)$ & $(0.05,0.48)$ \\
\hline res. in $v$. & 0.63 & 0.44 & 0.57 & 0.28 & 0.05 & 0.15 \\
\hline & $(0.39,0.79)$ & $(0.29,0.68)$ & $(0.43,0.74)$ & $(0.14,0.37)$ & $(-0.25,0.26)$ & $(-0.04,0.50)$ \\
\hline
\end{tabular}

Notes: Table reports the median of medians of the impulse responses. Values in brackets are the $16^{\text {th }}$ and $84^{\text {th }}$ percentiles of the distribution of medians and account for parameter uncertainty. 
Table 7. Results controlling for exchange rate regime

\begin{tabular}{lcccccc}
\hline & \multicolumn{2}{c}{ High } & \multicolumn{2}{c}{ Low } & \multicolumn{2}{c}{ Difference } \\
\cline { 2 - 7 } & $4 \mathrm{q}$ & $12 \mathrm{q}$ & $4 \mathrm{q}$ & $12 \mathrm{q}$ & $4 \mathrm{q}$ & $12 \mathrm{q}$ \\
\hline IMF Index & & & & & & \\
Monetary Policy Shock & & & & & \\
pr cred. & 0.21 & 0.40 & 0.24 & 0.29 & -0.03 & 0.11 \\
& $(0.10,0.31)$ & $(0.32,0.50)$ & $(0.10,0.35)$ & $(0.17,0.42)$ & $(-0.19,0.16)$ & $(-0.04,0.26)$ \\
house pr. & 0.22 & 0.41 & -0.04 & 0.18 & 0.29 & 0.24 \\
& $(0.12,0.36)$ & $(0.31,0.51)$ & $(-0.20,0.10)$ & $(0.07,0.32)$ & $(0.07,0.50)$ & $(0.05,0.37)$ \\
res. inv. & 0.37 & 0.36 & 0.02 & 0.16 & 0.35 & 0.22 \\
\multicolumn{1}{c}{$c$} & $(0.20,0.55)$ & $(0.24,0.52)$ & $(-0.18,0.26)$ & $(0.06,0.31)$ & $(0.04,0.61)$ & $(0.03,0.37)$ \\
Capital Inflows Shock & & & & & \\
pr cred. & 0.36 & 0.45 & 0.43 & 0.42 & -0.07 & 0.02 \\
& $(0.26,0.47)$ & $(0.33,0.57)$ & $(0.33,0.55)$ & $(0.31,0.59)$ & $(-0.23,0.08)$ & $(-0.15,0.18)$ \\
house pr. & 0.46 & 0.56 & 0.41 & 0.39 & 0.06 & 0.17 \\
& $(0.37,0.58)$ & $(0.42,0.78)$ & $(0.26,0.58)$ & $(0.26,0.57)$ & $(-0.13,0.22)$ & $(-0.02,0.41)$ \\
res. inv. & 0.70 & 0.54 & 0.31 & 0.37 & 0.36 & 0.14 \\
& $(0.47,0.82)$ & $(0.34,0.76)$ & $(0.12,0.53)$ & $(0.23,0.49)$ & $(0.05,0.65)$ & $(-0.03,0.42)$
\end{tabular}

MBS Index

Monetary Policy Shock

\begin{tabular}{lcccccc} 
pr cred. & -0.09 & 0.21 & 0.18 & 0.32 & -0.26 & -0.11 \\
& $(-0.26,0.08)$ & $(0.09,0.35)$ & $(0.09,0.26)$ & $(0.26,0.41)$ & $(-0.43,-0.11)$ & $(-0.26,0.03)$ \\
house pr. & 0.36 & 0.13 & 0.01 & 0.28 & 0.38 & -0.17 \\
& $(0.11,0.60)$ & $(-0.10,0.39)$ & $(-0.09,0.09)$ & $(0.20,0.34)$ & $(0.07,0.56)$ & $(-0.35,0.12)$ \\
res. inv. & 0.53 & -0.10 & 0.09 & 0.26 & 0.39 & -0.37 \\
& $(0.14,0.79)$ & $(-0.32,0.13)$ & $(-0.06,0.25)$ & $(0.18,0.33)$ & $(0.10,0.71)$ & $(-0.64,-0.08)$ \\
Capital Inflows Shock & & & & & \\
pr cred. & 0.47 & 0.62 & 0.37 & 0.28 & 0.13 & 0.34 \\
& $(0.32,0.64)$ & $(0.34,0.85)$ & $(0.28,0.46)$ & $(0.18,0.38)$ & $(-0.04,0.28)$ & $(0.09,0.57)$ \\
house pr. & 0.44 & 0.88 & 0.46 & 0.30 & -0.01 & 0.55 \\
& $(0.28,0.65)$ & $(0.44,1.20)$ & $(0.38,0.57)$ & $(0.20,0.43)$ & $(-0.21,0.19)$ & $(0.17,0.91)$ \\
res. inv. & 0.88 & 0.74 & 0.51 & 0.27 & 0.38 & 0.46 \\
& $(0.56,1.25)$ & $(0.34,1.23)$ & $(0.35,0.67)$ & $(0.17,0.39)$ & $(0.08,0.72)$ & $(0.10,0.90)$ \\
\hline
\end{tabular}

Notes: Table reports the results for a model which includes an interaction with an indicator equal to 1 if the exchange rate is fixed and 0 otherwise. The results in the table are obtained evaluating the model for countries without a peg (i.e. when the indicator takes the value 0 ). We report the median of medians of the impulse responses and in brackets are the $16^{\text {th }}$ and $84^{\text {th }}$ percentiles of the distribution of medians accounting for parameter uncertainty. 